Cryptocurrencies and the Evolution of Banking, Money and Payments

\title{
Benjamin Geva
}

Osgoode Hall Law School of York University, bgeva@osgoode.yorku.ca

\section{Source Publication:}

Chris Brummer (ed.) Cryptoassets Legal, Regulatory and Monetary Perspectives (Oxford University Press, 2019) pp.11-38

Follow this and additional works at: https://digitalcommons.osgoode.yorku.ca/scholarly_works

Part of the Banking and Finance Law Commons

\section{Repository Citation}

Geva, Benjamin, "Cryptocurrencies and the Evolution of Banking, Money and Payments" (2019). Articles \& Book Chapters. 2768.

https://digitalcommons.osgoode.yorku.ca/scholarly_works/2768

This Book Chapter is brought to you for free and open access by the Faculty Scholarship at Osgoode Digital Commons. It has been accepted for inclusion in Articles \& Book Chapters by an authorized administrator of Osgoode Digital Commons. 
Resubmitted-December 21, 2018

[For publication (by OUP) in a joint IMF-Georgetown book]

FINAL Submission

\title{
Final Version published in Chris Brummer (ed.) Cryptoassets Legal, Regulatory and Monetary Perspectives (Oxford University Press, 2019) 11-38
}

\author{
Georgetown-IMF \\ The Institute of International Economic Law (IIEL) \\ Georgetown Law / Georgetown University \\ $\underline{\text { Research and Policy Conference on Cryptoassets }}$
}

5-6 November, 2018

Georgetown Law and IMF Headquarters

Washington, DC, USA

Cryptocurrencies and the Evolution of Banking, Money and Payments

\author{
by \\ Benjamin GEVA* \\ Professor, Osgoode Hall Law School York University; Counsel, Torys LLP \\ Toronto, Canada \\ bgeva@osgoode.yorku.ca
}

This paper explores cryptocurrencies against the backdrop of the history of monetary, banking and payment systems, from a legal perspective. Providing a historical overview beginning in Antiquity, it explores just how today's cyber revolution compares against some key predicate operations, and situates cryptocurrencies in the context of the long-running evolution of bank payment intermediation and monetary development.

\section{$\underline{\text { Summary of Contents }}$}

\section{Introduction}

\footnotetext{
${ }^{*}$ For research assistance in the final preparation of the manuscript I am grateful to Alexander Davis of the 2019 Osgoode graduate class.
} 
II. Money, payment and payment intermediation

III. Deposit banking, payment services, and paper money: Historical perspective on payments intermediation

IV. The coming of the cyber age: Electronic payments, e-money, and access to central bank balances

V. Cryptocurrencies: Heralding a new form of money and payment disintermediation?

VI. Conclusion 


\section{Introduction}

In the modern economy, payments are typically made by means of transfers through bank accounts, and otherwise the delivery of cash in the form of banknotes and coins. As conduits of funds transfers, banks operate as intermediaries between payers and payees. They also distribute to their customers banknotes issued by the central bank. The recent emergence of cryptocurrencies, facilitating payments outside the banking system, as well as in items not created throughout banking operations, has put to test these fundamentals and particularly challenged the architectural premises of the present banking system.

This paper discusses cryptocurrencies in the context of an historical overview of the evolution of money, banking and the payment system. ${ }^{1}$ Part II addresses money, payment and payment intermediation. Drawing on my previous work, ${ }^{2}$ Part III sets out the evolution of commercial banking to facilitate national and global networks for book-based payments. Part IV takes us to the cyber-age. It addresses both electronic banking as a form of payment intermediation and the availability to the public of central bank balances as a challenge to payment intermediation. Cryptocurrencies, as a type of digital currencies, are discussed in Part $\mathbf{V}$, which goes on to examine the challenge they present to state-issued currency, payment intermediation, and the roles of banks in the payment systems. The Conclusion points at an irony: even as a challenge to banking, cryptocurrencies emerged as an outgrowth of an enhancement to banking. For their parts, centralized digital currencies may be linked to banking and the legacy monetary system. While changes of unknown scope and magnitude may be inevitable, banks, 'banking', and payment intermediation are unlikely to disappear.

\section{Money, payment and payment intermediation}

Money was defined to consist of anything which widely circulate as a medium of exchange so as to be accepted "in final discharge of debts ... without reference to the character or credit of the person who offers it and without the intention of the person who receives it to consume it ... " ${ }^{\prime 3}$ Over the centuries, coins and banknotes issued by the authority of the state have become the standard monetary objects in all countries, so as to collectively be called 'cash' or "currency."

The earliest coins were struck in Lydia (a city-state in Asia Minor) around 700 BCE. ${ }^{5}$ During Antiquity and the Middle Ages, having evolved from a commodity traded for its use-

\footnotetext{
${ }^{1}$ It has its genesis in "Banking in the Digital Age - Who is Afraid of Payment Disintermediation?" presented in Frankfurt, Germany on 23 \&24 February 2018 at the EBI Global Annual Conference on Banking Regulation), European Banking Institute Working Paper Series 2018 - no. 23, 59 Pages Posted: 2 Apr 2018; can be downloaded from: http://ssrn.com/abstract $=3153760$

${ }^{2}$ Particularly Chapters 2, 3, 8, and 10 of Benjamin Geva, The Payment Order of Antiquity and the Middle Ages: A Legal History (Oxford and Portland, Oregon: Hart Publishing, 2011

${ }^{3}$ Moss v. Hancock [1899] 2QB 111, 116. To the same effect see also: Reference Re Alberta Statutes [1938] S CR 100, 116, as well as Johnson v. State 52 So. 652 (Ala, 1910) and State v. Finnegean 103 NW 155 (Iowa, 1905).

4 "Both are not terms of art, so to speak. See e.g. in BA Garner, ed. in chief, Black's Law Dictionary, $9^{\text {th }}$ ed. (St. Paul MN: West, 2009) at 245, 440.

${ }^{5}$ This is the conclusion, confirming the conventional wisdom on the matter, of the thorough study by D. Kagan,

"The Dates of the Earliest Coins" (1982) 86:3 Journal of Archeology 343.
} 
value into currency transferred in payment of debts, ${ }^{6}$ the coin became the standard circulating object denoting a prescribed monetary value. ${ }^{7}$ It was fundamentally a piece of metal fashioned into a prescribed shape, weight, and degree of fineness, stamped by the issuer under the authority of the sovereign with certain designs, marks and devices. ${ }^{8}$ During the $17^{\text {th }}$ century CE, the banknote appeared as an obligation to pay coins or specie. Originally, the obligor thereon was a goldsmith, the predecessor of the deposit bank in England. ${ }^{9}$ Ultimately, in the course of the $18^{\text {th }}$ century, following the establishment of the Bank of England in 1694, ${ }^{10}$ the promise to pay on banknotes circulating as money became that of the central bank. ${ }^{11}$

At its inception, and in theory ${ }^{12}$ until the $19^{\text {th }}$ century CE, the value of a coin, at least its ideal form, was primarily determined by reference to the weight of the precious metal it contained. At the same time, by definition, inasmuch as they are mere obligations to pay, banknotes are 'fiat money', namely, of positive nominal value, notwithstanding the (relatively) worthless intrinsic value of the material of which they are made. ${ }^{13}$

Until the modern era, a monetary unit of account was anchored in the value of a specified weight of a prescribed metal. This gave the monetary unit of account its external value in terms of that metal, and facilitated the establishment of an international system under which the value of each national unit of account could be ascertained by reference to all other national units of account. ${ }^{14}$ Furthermore, until the modern era, the issuer's obligation to pay, measured by reference to a unit of account, was to actually pay that amount in specie, at least in coins. In

\footnotetext{
${ }^{6}$ For a comprehensive account see e.g. P. Gardner, A History of Ancient Coinage 700-300 BC (Chicago: Ares Publishers, 1974, being unchanged reprint of the Edition: Oxford, 1918).

${ }^{7}$ Roughly speaking, Antiquity comes to an end with the beginning of the Middle Ages, usually marked by the fall of Rome in $476 \mathrm{CE}$. The Middle Ages are commonly dated from the $5^{\text {th }}$ century fall of the Western Roman Empire until the fall of the Eastern Roman Empire in the $15^{\text {th }}$ century.

${ }^{8}$ See in general definitions of 'coin' in J. Burke, Jowitt's Dictionary of English Law, 2nd ed. (London: Sweet \& Maxwell, 1977) vol. 1 at 368. "Coin in French, signifieth a corner, and from thence hath its name..." See M. Hale, (d. 1676), The History of the Pleas of the Crown, $1^{\text {st }}$ American ed. by WA Stokes \& I. Ingresoll (Philadelphia: RH Small, 1847) vol. 1 at 187 , n. 2.

9 JM Holden, The History of Negotiable Instruments in English Law (London: Athlone Press, 1955; rep. Holmes Beach, Fla: Gaunt, 1993) at 70-73 and A. Feavearyear, The Pound Sterling - A History of English Money, $2^{\text {nd }}$ ed. by EV Morgan (Oxford, Clarendon Press, 1963) at 107-08.

$105 \& 6$ Will \& Mar. c. 20 s. XIX.

${ }^{11}$ An act of 1708, 7 Ann. c. 30 s. 66 forfeited the private note-issuing power of banking firms. Subsequently, under Country Bankers Act, 1826 (U.K.), 7 Geo. IV, c. 46, the note-issue power was restored to non-London bank.

Ultimately, this power was severely curtailed and subsequently disappeared following the passage of the Bank Charter Act, 7 \& 8 Vict., c. 32 in 1844. See Holden, supra note 9 at 87-94, 195-96.

${ }^{12}$ For an unequivocal legitimization of the King's power to control the metallic content of a coin irrespective of its denomination see Le Case de Mixt Moneys (1605), Davis 18, 80 E.R. 507.

${ }^{13}$ See Glossary in TJ Sargent \& F. Velde, The Big Problem of Small Change (Princeton and Oxford: Princeton University Press, 2002) at 375. The term is not conceptually different from 'token money' referring to a coin not having the intrinsic value for which it is current. Ibid. at 376.

${ }^{14}$ For the history of the international monetary system see e.g R. Lastra, Legal Foundations of International Monetary Stability (Oxford, Oxford University Press, 2006) at 345-70.
} 
England, this was originally true for banknotes issued by private bankers, ${ }^{15}$ and subsequently, to banknotes issued by the Bank of England. ${ }^{16}$ For a coin, the issuer's obligation was in the form of a guarantee as to its actual metallic content, or at least the redemption thereof.

To this day, current coins and banknotes are typically issued under state authority; at least for banknotes, the issuer is usually the central bank. However, other than the issue of coins and banknotes under state authority, by modern times, the framework just described above has been eroded. First, in the course of the $19^{\text {th }}$ century, the coin reflecting a fraction of the unit of account became a token, that is, a piece of metal of a value lower than which it denotes. The division of the basic unit of account into fixed token denominations at equal abstract sub-units ${ }^{17}$ is called by economists the "standard formula". ${ }^{18}$ Thereunder, the prescribed sum of such token denominations is convertible at a fixed exchange rate to each other denomination and to the basic unit, regardless of their own metallic composition. ${ }^{19}$

Next, in the first half of the $20^{\text {th }}$ century CE, convertibility of banknotes ceased to exist; that is, the obligation to pay in specie embodied in a banknote became unenforceable. ${ }^{20}$ Thus, at present, banknotes and coins express abstract obligations; they are tokens convertible to other tokens. Finally, during the second half of the $20^{\text {th }}$ century, even the measurement of the unit of account by reference to a specified quantity of a given precious metal was abolished. ${ }^{21}$ The external value of the standard national unit of value is now determined only by reference to the

\footnotetext{
${ }^{15}$ Such notes "accounted among merchants as ready cash". See Tassell and Lee v. Lewis (1696), 1 Ld. Raym. 743 at 744, 91 E.R. 1397 at 1398. However, "the acceptance [by a creditor] of ... [such a] note is not actual payment." Rather, "when such a note is given in payment, it is always intended to be taken under this condition, to be [absolute] payment [only] if the money be paid [in coin] thereon..." The condition was dispensed with upon the creditor's failure to demand payment in coin from the issuer "in convenient time." Ward v. Evans (1702), 2 Ld. Raym. 928 at 930, 92 E.R. 120 at 121.

16 Payment in Bank of England notes was held to be as good as "payment...in gold" so as to amount to absolute discharge. See Currie v. Misa (1875), LR 10 Ex 153 at 164. See also The Guardians of the Poor of the Lichtfield Union v. Greene (1857), 26 LJ Ex. 140 at 142. At the same time, while being legal tender under s. 6 of the Bank of England Act 1833 (U.K.), 3 \& 4 Will. 4, c. 98, actual convertibility to specie "had been an essential feature of the Bank of England Act 1833." Charles Proctor, Mann on the Legal Aspect of Money, $6^{\text {th }}$ ed. (Oxford: Oxford University Press, 2005) at 65.

${ }^{17}$ E.g. one dollar for one hundred pennies (each of one cent), twenty nickels (each of five cents), ten dimes (each of ten cents), or four quarters (each of twenty-five cents).

${ }^{18}$ See Sargent \& Velde, above note 13 at 5 (as well as Preface at XVII), specifically drawing on CM Cipolla, Money, Prices, and Civilization in the Mediterranean World, Fifth to Seventh Century (New York: Gordian Press, 1956) at 27. The triumph of the standard formula in the course of the $19^{\text {th }}$ century is set out by Sargent \& Velde, ibid., at 306-19.

${ }^{19}$ That is, one hundred pennies, twenty nickels, ten dimes, or four quarters are convertible to one dollar. Two nickels are converted to a dime, etc. Each such conversion is irrespective of the metallic content of the sub-unit denominations (that is, the penny, nickel, dime, or quarter). The "standard formula" preceded the cessation of convertibility (discussed in the immediately following paragraph); yet, as it is understood today, the "standard formula" does not rule out (nor does it require) that the basic unit, e.g. the dollar, be convertible or at least anchored to the value of a specified quantity of a given precious metal.

${ }^{20}$ In England, abolition of convertibility goes back to the Gold Standard Act, 1925 (U.K.), 15 \& 16 Geo. 5 , c. 29. Abolition was strengthened in Gold Standard (Amendment) Act, 1931 (U.K.), 21 \& 22 Geo. 5, c. 46. See Holden, supra note 9 at 279 .

${ }^{21}$ The 'cutoff' date is August 15 1971. On that day the US ceased to maintain the purchasing power of the US dollar in terms of a specified amount of gold. Thereby it effectively abolished the gold (or any other commodity) standard as the yardstick for the international monetary system. Until then, all currencies had been measured by reference to the US dollar, which is turn, had been assessed in gold. See Lastra, supra note 14 at 362-63.
} 
value in which that national unit of value is traded in international financial markets by reference to each other national units of accounts.

Payment in cash is by physical delivery from one person (payer) to another (payee). This is a face-to-face process which does not requires intermediaries. More specifically, 'payment' is "a bilateral act which requires the [payee] to accept the [payer]'s act of tender"; 22 and is completed on the passage of possession in the money ${ }^{23}$ when the payee takes delivery, thereby manifesting the acceptance of the tender. ${ }^{24}$

From the beginning, payment in cash had flaws, and under some circumstances was impractical. Particularly, this is due to costs and risks associated with the storage, carriage and transportation of cash. Other concerns have been scarcity of cash and the inevitable cumbersome process of handling and paying in cash large sums of money. In a nutshell, an effective solution has been in the form of payment made to the payee, under the payer's instructions, by an intermediary who typically owed money to the payer. ${ }^{25}$ Such payment would discharge both the payer's debt to the payee and the intermediary's debt to the payer. An optimal such an intermediary was a deposit-taker, i.e. banker, being a debtor to all depositors. When payee preferred payment into payee's account with another banker (rather than in cash) the two bankers, that of the payer and that of the payee, settled periodically by paying the balance due for customers' payments going in both directions. Bankers kept funds with each other and ultimately with a central counterparty. Over the centuries, both national and global non-cash payment systems so evolved.

At the heart of such a system stands the commercial bank. The essence of commercial banking has been the taking of deposits (or other repayable funds) from the public and lending. ${ }^{26}$ Linked to these functions is the provision of inter-account payment services. ${ }^{27}$

Historically, commercial banking (banking) emerged as a form of financial intermediation between savers (depositors) and borrowers. The banker (or bank) ${ }^{28}$ took from the public deposits either in specie or in commodity money; what was deposited was both owed by the banker to the depositors and at least in part available to be lent by the banker to borrowers.

\footnotetext{
22 David Fox, Property Rights in Money (Oxford: Oxford University Press, 2008) at 28.

${ }^{23}$ Hence, contract alone cannot transfer the legal title to money. Fox, ibid. at 87.

${ }^{24}$ Fox, ibid. at 79-86, and further, at 87-95.

${ }^{25}$ Alternatively, having paid the payee, an intermediary who did not owe money to the payer, became owed by the payer.

${ }^{26}$ See e.g. definition of 'credit institution' in Article 4(1)(1) of Regulation (EU) No 575/2013 of the European Parliament and of the Council of 26 June 2013 on prudential requirements for credit institutions and investment firms and amending Regulation (EU) No 648/2012, online: http://eur-lex.europa.eu/legalcontent/EN/TXT/?uri=celex:32013R0575, accessed December 22, 2017. http://eur-lex.europa.eu/legal-content/EN/TXT/?uri=celex:32013R0575, accessed December 22, 2017.

${ }^{27}$ Edwin Green, Banking: An Illustrated History (New York: Rizoli, 1989) at 11. For a similar judicial discussion on the characteristics of banking see Lord Denning MR judgement in United Dominion Trust v. Kirkwood [1966] 2 QB 31 (CA) at 445-447.

${ }^{28}$ Grammatically, 'banker' is the professional individual, while 'bank' is the institution. Until incorporation, there was no real difference and this paper will use to the two terms interchangeably. Note also that 'commercial banking', 'banking', and 'deposit banking' are, generally speaking, synonyms, and unless indicated otherwise are used in this paper interchangeably.
} 
Loans were mostly credited into borrowers' deposit accounts with the lending bankers in part to be used by borrowers to make payments. In this environment, payment intermediation in the form of non-cash payment services evolved as an outgrowth of deposit taking or, more in general, of maintaining deposit accounts for customers, whether the original depositors, or the borrowers who deposited the proceeds of the loan. ${ }^{29}$ This business model has been workable as long as not all depositors required payment in specie from the banker at the same time. In normal circumstances, it sufficed for a banker to keep at hand enough specie or cash to satisfy reasonable demand. Monitoring depositors' payment activity in accounts facilitated credit decision-making and led to specialization in advancing information-intensive non-traded loans, which became a principal niche for a profitable commercial banking business as well as effective financial intermediation for the economy as a whole.

Already way back in Antiquity ${ }^{30}$ the evolution of mechanisms for payments initiated by the issue of payment orders had been part and parcel of the emergence of 'banking' as a form of financial intermediation between depositors to, and borrowers from, the depositary. ${ }^{31}$

Furthermore, over centuries the architecture of the banking system evolved to satisfy the need to carry out noncash payment transactions between customers of separate banks by the creation of interbank networks. For its part, lending out of deposits generated a fractional reserve system which necessitated the establishment of liquidity facilities to ensure the smooth flow of payments. Finally, for their part, banknotes, of which at present mainly consists cash, originated as circulating receipts for deposited funds.

\section{Deposit banking, payment services, and paper money: Historical perspective on payments intermediation}

The modern payment system has been described to consist of "a complex set of arrangements involving such diverse institutions as currency, the banking system, clearing houses, the central bank, and government deposit insurance." 32 The latter element is helpful but not universally present; and yet all are components of what can broadly be described as a commercial (deposit) banking system.

\footnotetext{
${ }^{29}$ See e.g. Meir Kohn, "Early Deposit Banking” (February 1999) Department of Economics Darmouth College, Working Paper 99-03, online: <http://sites.dartmouth.edu/mkohn/files/2017/03/99-03.pdf>, accessed 9 January 2018; and James McAndrews and William Roberds, "Payment Intermediation and the Origins of Banking" (August 1999) Federal Reserve Bank of Atlanta, Working Paper 99-11, online:

<https://www.frbatlanta.org/research/publications/wp/1999/11.aspx>, accessed 9 January 2018. Both studies cover the Middle Ages and overlook Antiquity.

${ }^{30}$ Roughly speaking, Antiquity comes to an end with the beginning of the Middle Ages, usually marked by the fall of Rome in $476 \mathrm{CE}$.

${ }^{31}$ For an insight into the process, though well into the later Medieval period, see e.g. Abbot Payson Usher, The Early History of Deposit Banking in Mediterranean Europe vol 1 (Cambridge, Mass: Harvard University Press, 1943) particularly at 3-25.

${ }^{32}$ MS Goodfriend, "Money, Credit, Banking, and Payment System Policy", in David B Humphrey, The US Payment System: Efficiency, Risk and the Role of the Federal Reserve (Boston: Kluwer Academic Publishers, 1990$)$ at 247.
} 
Notwithstanding the substantial enhancement in complexity and importance of banking in the modern economy, its fundamentals are not at all novel. ${ }^{33}$ What follows is an abbreviated account of the evolution of payment intermediation and that of paper money as an outgrowth of deposit banking.

\section{(i) $\quad$ Antiquity}

Ancient Mesopotamia has been identified as the cradle of banking operations. ${ }^{34}$ It earned this title due to the emergence of institutions providing all core banking activities, namely, deposit taking, lending ${ }^{35}$ and payment services even prior to the emergence of 'monetized' coins. However, this was a secondary activity for such institutions; moreover, credit was made available by depositaries out of their own capital ${ }^{36}$ and without dipping into deposits. ${ }^{37}$ As well, each customer's deposit may have been physically segregated. ${ }^{38}$ Payment and withdrawal orders were inscribed on tablets, and yet could be oral. Each payment order directed the drawee to pay either to a payee known to the drawee or to a payee to be properly identified. ${ }^{39}$ Payment was made in specie; there appears to be neither evidence for the execution of non-cash payments from one account to another nor any trace of inter-institutional clearing and settlement.

There is a historical debate on the possible origins of money in the Ancient East, particularly in Mesopotamia; specifically, there is a disagreement on whether distinct items of

\footnotetext{
${ }^{33}$ But cf. William Linn Westermann, "Warehousing and Trapezite Banking in Antiquity" (1951) 3 Journal of Economic and Business History 30 at 31 who highlights "a sound contrast between the relatively simple services rendered by the bank and the banker in antiquity ... and the commanding position and complex character of banking as a function of credit in the economic system of today." No doubt, such a contrast really exists, and yet it is not on point in tracing the roots of the modern bank to its predecessor in Ancient Greece.

${ }^{34}$ Raymond Bogaert, Les Origines antiques de la banque de dépôt (Leyde: A. W. Sijthoff, 1966) at 129 [Bogaert, Les Origines]. Roughly speaking, at 41-129, Bogaert surveys a period extending over 1500 years commencing at the end of the $21^{\text {st }}$ century BC and covering the Ur III Empire (2112-2004 BCE), the Old Babylonian Period (20001600 BCE) which included the reign of Hammurabi (1792-1750 BCE), the Middle Assyrian and Middle Babylonian Periods (1200-750 BCE), and the Neo-Assyrian and Neo-Babylonian Kingdoms (745-539 BCE). Elsewhere in the book, at 43, Bogaert specifically discounts the existence of any comparable role to Pharaonic Egypt, the other Ancient Near Eastern civilization.

${ }^{35} \mathrm{~A}$ complex system of lending is traced back in Mesopotamia to the first half of the $2^{\text {nd }}$ millennium BCE. See in general, Katrien De Graefe, "Giving a Loan is Like Making Love..." in Koenraad Verboven, Katelijn Vandorpe \& Véronique Chankowski, eds, Pistoi Dia Tèn Technèn-Bankers, Loans and Archives in the Ancient World: Studies in Honour of Raymond Bogaert (Leuven: Peeters, 2008) at 3 [Verboven et al., Ancient World].

${ }^{36}$ Bogaert, Les Origines, supra note 34 at 174.

${ }^{37}$ The gradual erosion during the first millennium BCE, culminating approximately at the first part of its second half, is noted by Francis Joannès, "Les activités bancaires en Babylonie" in Verboven et al., Ancient World, supra note 35 at 17, 19. The claim set out in Alexander Lipton and Alex "Sandy" Pentland, "Breaking the Banks: New Financial Networks Could stop the Concentration of Wealth and Increase Participation in the Economy -But only If Handled with Care" (January 2018) 318:1 Scientific American 26 who identify the origins of fractional lending out of deposits "more than 5,000 years ago in the Mesopotamian city of Ur" is supported by neither Joannès, ibid nor Bogaert, Les Origines, supra note 34 to whose expertise I prefer to defer.

${ }^{38}$ Bogaert, Les Origines, note 34 at 59, 84 n.236, 99 and nn. 311-313 \& text, supra.

${ }^{39}$ Bogaert, Les Origines, ibid. at 99 . For written orders issued by a lender temple directed to a warehouse or granary at the locality of the payee- borrower see Bogaert, ibid. at 54. An order to a non-depositary obligor could be either written or oral. Ibid. at 100.
} 
value were actually used exclusively as means of payments, and thus approximated coins. ${ }^{40}$ However, it seems to be universally agreed that nascent 'banking operations' in Mesopotamia preceded the emergence of money, in the sense of standardized metallic pieces, in fixed denominations, whose value is certified by the ruler's stamp. ${ }^{41}$ Rather, various commodities served as both units of account and means of payment. Based on their comparative or relative value, such commodities served as a basis for a price system, as well as actual means or money of payment. Principal commodities were grain and precious metal, usually barley and silver. ${ }^{42}$ Having both (i) actual use value or intrinsic utility, and (ii) economic value facilitating their use to provide a standardized means for both the measurement for the value of other commodities as well for paying for all such other commodities, such items constituted 'primitive money'. ${ }^{3}$

The emergence of the bank as a distinct type of institution took place in Ancient Greece. ${ }^{44}$ More specifically, the process took place in the Mediterranean territory on which Ancient Greek civilization expanded, ${ }^{45}$ almost throughout the entire classical period of that civilization. $^{46}$

${ }^{40}$ Proponents include M. Balmuth, "The Monetary Forerunners of Coinage in Phoenicia and Palestine" in A. Kindler, ed., The Patterns of Monetary Development in Phoenicia and Palestine in Antiquity (Tel Aviv: Schocken, 1967) (Proceedings of the International Numismatic Commission, The Israeli Numismatic Society, International Numismatic Convention, Jerusalem 1963) at 25; M. Balmuth, "The Critical Moment: the transition from currency to coinage in the eastern Mediterranean" (1975), 6 World Archeology 293; and J. Dayton, "Money in the Near East Before Coinage" (1974), 23 Berytus Archaeological Studies 41. For a critique see MA Powell, "A contribution to the History of Money in Mesopotamia prior to the Invention of Coinage" in B. Hruška \& G. Komoróczy, eds., Festschrift Lubor Matouš, Volume 2 (Budapest, Eötvös Loránd Tudományegyetem, Ókori Történeti Tanszek 1978) at 211. Another skeptic is P. Grierson, The Origins of Money (London: The Athlone Press, 1977, being the Creighton Lecture in History, 1970) at 8 \& n. 7.

${ }^{41}$ The earliest coins were struck in Lydia (a city-state in Asia Minor) around 700 BCE. See Part II, supra.

${ }^{42}$ See in general RFG Sweet, On Prices, Money and Money Uses in the Old Babylonian Period (Unpublished Ph. D dissertation submitted to the Department of Oriental Languages and Civilizations of the University of Chicago, IL, 1958, available through UMI Dissertation Services, Ann Arbor Michigan); and MA Powell, "Identification and Interpretation of Long Term Price Fluctuations in Babylonia: More on the History of Money in Mesopotamia" (1990), 17 Altorientalische Forschungen 76. See also JN Postgate, above note 10, who in discussing (at 202-205) currency, observed (at 204) that "In the early second millennium, silver was the preferred currency of the merchant classes and perhaps of the administration, but even in the Old Babylonian times ... the administration and the private sector regularly used [also] barley to fulfil much the same function, and other commodities are also attested."

${ }^{43}$ According to P. Einzig, Primitive Money, $2^{\text {nd }}$ ed. (Oxford: Pergamon Press, 1966) at 317, primitive money was "a unit or an object conforming to a reasonable degree to some standard of uniformity, which is employed for reckoning or for making a large proportion of the payments customary in the community concerned, and which is accepted in payment largely with the intention of employing it for making payments." For primitive money see also AJ Toynbee, A Study of History, Abridgement of Volumes VII-X by DC Somervell (London: Oxford University Press, 1957) at 60 and in this study, Chapter 2, Section 1, particularly §1.2, above.

${ }^{44}$ The ensuing discussion draws on Raymond Bogaert, Banques et banquiers dans les cités grecques (Leyde: A.W. Sijthoff, 1968) at 50-60 and 331-345 [Bogaert, Banques et banquiers]; Bogaert, Les Origines, supra note 34 at 130158; Edward E Cohen, Athenian Economy and Society: A Banking Perspective (Princeton NJ: Princeton University Press, 1992) at 8-11, 14-18, 62-66 and 111-121.

${ }^{45}$ Roughly speaking this territory covers Mainland Greece, Greek Islands (together roughly coinciding with the area of modern-day Greece), and the western coast of Asia Minor or Anatolia (the latter of which is part of modern-day Turkey).

${ }^{46}$ The Classical Period is said to have lasted between 500 and 336 BCE. It was preceded by the Archaic Period (stretching from 750 to $500 \mathrm{BCE}$ ) and followed by the Hellenistic Period (taking place between 336 and $146 \mathrm{BCE}$ ). The latter commences with Alexander the Great (336 to 323 BCE) under whose reign Greek civilization extended 
Thus, in the course of the $6^{\text {th }}$ century BCE, shortly after the appearance of coined money as a medium of exchange in commercial transactions, ${ }^{47}$ money changing surfaced as a profession. Shortly thereafter, the moneychanger came to accept deposits of coined money, mix them, ${ }^{48}$ lend out of them, so as to gradually become a banker. A banker effectively kept a running account for each customer, posting to it each deposit and withdrawal. ${ }^{49} \mathrm{~A}$ withdrawal from a customer's account could be made for the entire or part of a balance due on deposited money, either by the depositor himself, or by a designated payee (or on his behalf) in pursuance to the depositor's instruction.

For each payment to a designated payee, having received the payment order and being in possession of cover, the payer's banker sent a note to the payee. Having made an appropriate entry on his books in the payee's favour, the banker became accountable to the payee, regardless of whether the payee kept an account with that banker. A payee who did not have an account of the payer's bank could demand payment in cash. Alternatively, where the advice note issued by the payer's banker was made out to the payee 'or order', the payee could appoint an agent, usually another banker, to come to the payer's banker and claim on the payee's behalf payment in cash over the counter. In the further alternative, the payee's banker may have been prepared to act on the basis of the advice note issued to the payee by the payer's banker. In such a case, upon the presentment of the advice note, the payee's banker credited the payee's account in advance, in anticipation of subsequent payment by the payer's banker. Payment by payer's banker to the payee's banker could be effectuated either in coins, or as part of either bilateral or multilateral setoff. No interbank clearing system, whether bilateral or multilateral, existed in Ancient Greece. ${ }^{50}$

eastwards where it met and mingled with Eastern civilization. For time periods in the history of Ancient Greece you may visit <http://en.wikipedia.org/wiki/Timeline_of_ancient_Greece>, accessed 27 December 2017.

${ }^{47}$. Both the production and use of coined money were expanded towards the end of the $6^{\text {th }}$ and beginning of the $5^{\text {th }}$ century BCE. See in general, Arthur R Burns, Money and Monetary Policy in Early Times (New York: A.M. Kelley, 1965 , reprint of 1927) at 43-45.

${ }^{48}$ On the theory that the depositary thus became indebted for the amount of the deposit rather than to return it in specie, Bogaert, Banques et banquiers supra note 44 at 333 treats such a deposit as 'irregular' in the sense subsequently given to it by the Romans. In the view of Cohen, supra note 44 at 112-113 this is however an anachronism.

${ }^{49}$ On the evolution of accounting in Greece see e.g. Léopold Migeotte, "La compatabilité publique dans les cités Grecques: l'exemple de Délos" in Verboven et al., Ancient World, supra note 35 at 59, and Véronique Chankowski, "Banquiers, caissiers, comptables. À propos des méthodes financières dans les comptes de Délos" in Verboven et al., Ancient World, supra note 35 at 77.

${ }^{50}$ Bogaert, Banques et banquiers supra note 44 at 344-345 and 413. 
Compared to Ancient Greece, the institutional scene in Ancient Rome ${ }^{51}$ was more complex; ${ }^{52}$ and yet, this complexity did not lead to an overall advancement in banking practices. Nonetheless, in three major respects Roman banking practice went beyond that of the Greek. First, the receiver-banker could be treated as the first money transmitter, to whom funds are delivered with the view of making a specific payment. However, money transmission by a receiver-banker may have developed under narrow circumstances, in the context of private auctions, ${ }^{53}$ and in any event did not extend to cover payments between geographically distant parties. Second, as in Ancient Greece, there was in Ancient Rome neither an intra-city nor intercity multilateral interbank clearing and settlement system. ${ }^{54}$ However, nascent interbank correspondent arrangements, under which one bank held funds in an account with the other, developed, particularly in the same city, ${ }^{55}$ but also in different cities so as to facilitate payments between geographically distant parties. ${ }^{56}$ A non-cash payment could have been carried out between accounts of two depositors, either in the same bank, or in two banks situated in the same small town or within a specific market, whether permanent or periodic.

Third, deposit bankers operated under strict bookkeeping requirements, and were obligated to record their monetary operations in account books called rationes. An account book (ratio in singular) was also known as a ratio accepti et expensi ('an account of deposits and payments') and ratio implicita proper accepta et data ('a complex account including both

\footnotetext{
${ }^{51}$ Between around $500 \mathrm{BCE}$ and $30 \mathrm{CE}$ the Roman Republic grew from a city state to dominate first Italy, then the Western Mediterranean and, finally, the entire Mediterranean basin. In the process, Rome had undergone a fundamental change in its system of government and came to be the Roman Empire. The City of Rome ultimately fell at $476 \mathrm{CE}$, an event which marks the end of the Roman period in the West. An outline of Roman history can be found, for example, at <http://www.forumromanum.org/history/>, accessed 28 December 2017. In 320 CE Emperor Constantine chose Byzantium (present-day Istanbul) as the new capital of the Empire and renamed it Constantinopolis. He officially divided the Empire into an Eastern and Western Empires in 395 CE. The Eastern Empire survived for close to 1,000 years after the fall of Rome, until Constantinopolis fell to the hands of the Ottoman Turks in $1453 \mathrm{CE}$, except that particularly as of the rise of Islam at the $7^{\text {th }}$ century CE it had been considerably weakened long before its ultimate fall.

${ }^{52}$ For this institutional framework see e.g. Jean Andreau, Banking and Business in the Roman World (Cambridge: Cambridge University Press, 1999) at 30-49 [translated by Janet Lloyd] [Andreau, Banking] at 30-49; as well as Koenraad Verboven, "Faeneratores, Negotiatores, and Financial Intermediation in the Roman World (Late Republic and Early Empire)" in Verboven et al., Ancient World, supra note 35 at 211; and Koenraad Verboven, "The Sulpicii from Puteoli, argentarii or faeneratores?" in Pol Defosse, ed, Hommages à Carl Deroux; III -Histoire et épigraphie, Droit (Bruxelles: Éditions Latomus, 2003) at 429. See also Peter Temin, "Financial Intermediation in the Early Roman Empire" (2004) 64.3 Journal of Economic History 705.

${ }^{53}$ See in general, Hubert Cancik and Helmuth Schneider, eds, Brill's New Pauly Encyclopedia of the Ancient World: Antiquity, vol 2 (Leiden-Boston: Brill, 2003) at 331 (v. "Auctiones"). See also G. Humbert, "Auctio", in Charles Victor Daremberg and Edmond Saglio, eds, Dictionnaire Des Antiquités Greques et Romaines vol 1, Part 1 (Graz: Akademische Durck- u. Verlagsanstalt, 1969) at 543. For the controversy as to the role the banker played in a public auction see e.g. Fritz Sturm, "Stipulation argentaria" in Felix Bernard Joseph Wubbe \& Johan Albert Ankum, Mélanges Felix Wubbe: offerts par ses collègues et ses amis à l'ocassion de son soixante-dixiéme anniversaire (Fribourg: Éditions universitaire, 1993) at 453, 460-63; Hans Ankum, "Quelques problèmes concernant les ventes aux enchères en droit romain classique", Studi in onore di Gaetano Scherillo, vol 1, 377 (Milan: Cisalpino-La goliardica, 1972); and JAC Thomas, "The Auction in Roman Law" (1957) Juridical Review 42.

${ }_{54}$ Notwithstanding Sam Maxwell, De la délégation en droit romain (Bordeaux: Imprimerie $\mathrm{V}^{\mathrm{e}}$ Cadoret, 1895) at 111.b

${ }^{55}$ See Andreau, Banking, supra note 52 at 43, who specifically claims that in the Roman world "[t]here was no system of institutionalized compensation between banks of the same city."

${ }^{56}$ See Jean G Platon, Les Banquiers dans la législation de Justinien (Premiére partie) (Paris: Librairie Recuil Sirey, 1912) at 108-09.
} 
deposits and payments'). A deposit banker was required to make such books available for production in a trial involving a client, even where the deposit banker was not a party to the litigation. ${ }^{57}$ For his part, the deposit banker was obligated to maintain books, to account for the various entries, and to state a balance owed between himself and the customer. ${ }^{58}$

Payment services were operated in conjunction with deposit banking in Greco-Roman Egypt ${ }^{59}$ Public granaries in Greco-Roman Egypt, connected into a network of grain depositaries, operated a countrywide system of payment in agricultural products, such as oil and wine. Particularly however, they ran grain warehouse banking, facilitating payments out of and into deposits of grain, for both public authorities and individuals. ${ }^{60}$ The system maintained grain accounts and recorded transfers. For each yearly harvest of each type of grain the various deposits were physically amalgamated so that credit to an account reflected a claim to a share in the mixture rather than to a physically segregated or separate deposit; it seems though, that no lending was made out of the mixture, so that full reserve was held to back all credits to the deposit accounts. ${ }^{61}$

Book-based transfers could occur between accounts in the same granary, same region, or different regions. For an inter-granary transfer, an adjustment was made not only to transferor's and transferee's accounts, but also over a system of inter-granary accounts. ${ }^{62}$ A comprehensive account management system thus existed in each granary, in each region, as well as in Alexandria, from which the entire system was overseen. Effectively, this was the forerunner for a

\footnotetext{
57 See Adolf Berger, Encyclopedic Dictionary of Roman Law (Philadelphia: American Philosophical Society, 1953) at 366-367 (v. "Argentarii”).

${ }^{58}$ Edmond Guillard, Les Banquiers Athéniens et Romains suivis du Pacte de Constitut en Droit Romain (Paris, Lyon: Guillaumin, H. Georg, 1875) at 52 sets out these obligations and discusses them at length in 52-79.

${ }^{59}$ Following the death of Alexander the Great in 323 BCE, and after the ensuing partition of his empire, Egypt fell into Ptolemy's hands. His successors, the Ptolemies, ruled Egypt until 30 BCE when the country was conquered by the Romans. With the partition of the Roman Empire in the course of the $4^{\text {th }}$ century CE, the Byzantines succeeded the Romans; they stayed in power until $642 \mathrm{CE}$, when the Arabs took over and the Islamic epoch commenced. For Egypt, the entire era of close to a millennium, between Alexander the Great and the introduction of Islam, is loosely referred to as Greco-Roman. This historical sketch draws on <http://www.sis.gov.eg/section/0/701?lang=en-us>, accessed 27 December 2017, and <http://en.wikipedia.org/wiki/Alexander_the_Great $\geq$, accessed 27 December 2017. See also <http://en.wikipedia.org/wiki/Roman_Empire >, accessed 27 December 2017, and <http://en.wikipedia.org/wiki/Muslim_conquests>, accessed 27 December 2017.

${ }^{60}$ The system is concisely described by Claire Préaux, L'Économie royale des Lagides (Bruxelles: Édition de la Fondation Égyptogique, 1939) at 142, as well as by Michael Rostovtzeff, The Social and Economic History of the Hellenistic World, vol 2 (Oxford: Clarendon Press, 1941) at 1287. See also Gyles Davies, A History of Money: from Ancient Times to Present Day, 3rd ed (Cardiff: University of Wales Press, 2002) at 52-55 and Westermann, supra note 33 at 32-33. The authoritative text relied by all is in German: Friedrich Preisigke, Girowesen im griechischen Ägypten (Strassburg: Verlad von Schlesier \& Schweikhardt, 1910) [Reprinted: Hildesheim, New York: Georg Olms Verlag, 1971], discussing the grain giro system at 62-184, particularly at 89-92, 101-102, and 128-130 (see also relevant translated documents reproduced at 147-173), in connection with which I had the benefit of a partial unofficial translation.

${ }^{61}$ For this understanding of the system (on the basis of Westermann's article, supra note 33) see Jeffery Williams, "Fractional Reserve Banking in Grain" (1984) 16 Journal of Money, Credit and Banking 488 at 488 n. 1.

${ }^{62}$ For example, a transfer from a Depositor A in Granary A to a depositor B in Granary B, resulted not only in an adjustment of Depositors' accounts, but also in an adjustment that reflected the claim of Granary B on Granary A where the grain in the amount of the transfer remained kept.
} 
nationwide credit-push giro mechanism, ${ }^{63}$ under which payment orders were executed by means of crediting and debiting accounts. ${ }^{64}$ The system was however doomed to wither away together with the disappearance of specie and kind as universal mediums of exchange. ${ }^{65}$

So far as the monetary economy of Greco-Roman Egypt ${ }^{66}$ was concerned, the banking system formed a network and assumed a key role in carrying out treasury operations for the central government and other public authorities. Each regional royal bank operated in conjunction with a network of village banks, which effectively functioned as branch offices for royal banks or more precisely, as points of collections and disbursements of funds ${ }^{67}$ throughout the various districts of the country. However, the Royal Treasury, or the basilicon, in Alexandria, ${ }^{68}$ did not serve as a central bank; ${ }^{69}$ it neither maintained accounts for all deposits throughout the country, nor received surplus balances for such accounts, other than for the king. Nor did the basilicon oversee the operation of the entire network; it did not even maintain accounts for the various royal banks into which adjustments for inter-district transfers could be made. Rather, each royal bank kept a separate set of records for its own account holders. Effectively, together with its village bank network, a royal bank operated as a standalone

63 'Giro' (coming from Greek 'gigros', and meaning ring, circular or cyclical) usually narrowly denotes a 'creditpush' mechanism for a non-cash payment between two accounts (as in http://en.wikipedia.org/wiki/Giro, accessed 27 December 2017). Alternatively, it may more broadly denote any bookkeeping transfer (as in Westermann, supra note 33 at 49) or transfer operations (as in Rostovtzeff, supra note 60 at 1279). In this latter (broad) sense it is any non-cash payment between two bank accounts, regardless of whether it is a 'credit-push' or 'debit-pull' mechanism. ${ }^{64}$ Possibly also, circulating credit notes attesting to credit posted to a grain account are said to have been used as payment devices. See e.g. Roger S Bagnall and Raymond Bogaert, "Orders for Payment from A Banker's Archive: Papyri in the Collection of Florida State University" (1975), in Raymond Bogaert, Trapezitica Aegyptiaca: Recueil de recherches sur la banque en Égypte Gréco-Romaine (Firenze: Edizioni Gonelli, 1994) at 240 [Trapezitica]. No mention of such credit notes appears in Preisigke, supra note 60.

${ }^{65}$ And yet, a temporary revival of grain banking, consisting also of lending out of amalgamated deposits, occurred in the Chicago in the course of the $19^{\text {th }}$ century. See Williams, supra note 61.

${ }^{66}$ Bogaert researched and wrote extensively on the subject. His work, consisting of 20 articles, mostly in French, to 1994 (originally published elsewhere) is collated in Trapezitica, supra note 64. Six subsequent articles (which are thus not part of the collection) are Raymond Bogaert, "Liste géographic des banques et des banquiers de l'Égypte romaine, 30A-284" (1995) 109 Zeitschrift-für Papyrologie und Epigraphik 133; Raymond Bogaert, "La Banque en Égypte Byzantine" (1997) 116 Zeitschrift-fur Papyrologie und Epigraphik 85; Raymond Bogaert, "Les opérations des banques de l'Égypte Ptolémaïque" (1998) 29 Ancient Society 49; Raymond Bogaert, "Liste géographique des banques et des banquiers de l'Égypte Ptolémaïque" (1998) 120 Zeitschrift-für Papyrologie und Epigraphik 165; Raymond Bogaert, "Les opérations des banques de l'Égypte romaine" (2000) 30 Ancient Society 135; and Raymond Bogaert, "Les documents bancaires de l'Égypte Gréco-Romaine et Byzantine" (2001) 31 Ancient Society 173. Bogaert commenced the first of these last six articles ("Liste geographic" (1995), ibid at 133 text at n. 1) by conceding that for health reasons he had abandoned his plan to synthesize his extensive research on banks in GrecoRoman Egypt into a monograph. Since then, he unfortunately passed away (in October 2009). A recent work covering the first part of the period is Sitta von Reden, Money in Ptolemaic Egypt: From the Macedonain Conquest to the End of the Third Century BC (Cambridge: Cambridge University Press, 2007) at 257-296.

${ }^{67}$ From a modern perspective, they were not 'bank branches' as, per explanation that immediately follows, they did not maintain on their books the principal accounts of their customers.

${ }^{68}$ Bogaert's tentative statement to that effect in Bogaert, "Le statut des banques en Égypte Ptolémaïque" (1981), Trapezitica, supra note 64 at 56 as well as in Bogaert, "Recherches sur la banque en Égypte Gréco-Romaine" (1987), Trapezitica, supra note 64 at 6 is expressed more confidently in Bogaert, "Les opérations des banques de l' Égypte Ptolémaïque" supra note 66 at 117.

${ }^{69}$ Among others, this has been a contested point. The present analysis follows Bogaert, who on this issue determined against the existence of a central bank in Alexandria. For his view on the point, in conjunction with a survey of the debate, see e.g. Bogaert, "Le statut des banques en Égypte Ptolémaïque" ibid at 47. 
independent bank. It follows that there was no infrastructure facilitating a countrywide system for inter-district non-cash payments from an account in one royal bank to an account in another.

Throughout the Ptolemaic era, ${ }^{70}$ both royal and private banks maintained deposit accounts for individuals. ${ }^{71}$ Available documentation supports the existence of funds transfers from one account to another ${ }^{72}$ in private banks ${ }^{73}$ as well as for tax payments from accounts maintained in royal banks. ${ }^{74}$ Documentation further supports the existence of bilateral correspondent relations between private banks, namely instances where one bank holds an account with another.$^{75}$ At the same time, there is no indication of any multilateral bank clearing arrangement; and certainly, any claim to the existence in Greco-Roman Egypt of a "centralized state giro system"76 is not well founded.

Royal banks in Ptolemaic Egypt pioneered a nascent cheque system. ${ }^{77}$ The drawer would issue a non-transferable cheque to the payee and send a 'control note' to the drawee bank which would match it with the cheque upon its presentation. Cheques were non-transferable. The payee would present the cheque to the payer's bank, either in person or through an agent, and be paid usually in cash Alternatively, the payee could have his account credited with the payer's bank. In the further alternative, where the payer's bank kept an account with the payee's bank, payee would instruct the payer's banker to draw on the payee's banker a cheque payable to the payee. The payee would then present that cheque to the payee's bank, which would then debit the account of the payer's bank and credit that of the payee. Being drawn by one bank on another, the cheque issued by the payer's bank was the forerunner of a bank draft or money order. ${ }^{78}$ Cheque use has been eclipsed in Egypt in the course of the Roman period. ${ }^{79}$

\section{(ii) $\quad$ Middle Ages}

\footnotetext{
70 The Ptolemies, ruled Egypt following the death of Alexander the Great in 323 BCE until 30 BCE when the country was conquered by the Romans. See note 59 supra.

${ }^{71}$ Bogaert, "Les opérations des banques de l'Égypte Ptolémaïque", supra note 66 respectively at 113-116, 124-128, 135-142.

72 Bogaert, ibid.

73 Bogaert, ibid at 136-137.

${ }^{74}$ Bogaert, ibid at 115 .

75 Bogaert, ibid at 135.

${ }^{76}$ Davies, supra note 60 at 92.

${ }^{77}$ Bogaert, Banques et banquiers supra note 44 at 340-341, particularly at text at n. 206; Roger. S. Bagnall and Raymond Bogaert, “Orders for Payment from A Banker's Archive: Papyri in the Collection of Florida State University" (1975), in Trapezitica, supra note 64 at 219

${ }^{78}$ For legal aspects of these instruments under modern law see e.g. Benjamin Geva, "Irrevocability of Bank Drafts, Certified Cheques and Money Orders" (1987), 65 Can. Bar Rev. 107.

${ }^{79}$ For a cheque from Roman Egypt from $125 \mathrm{CE}$, giving rise to a dispute involving the unavailability of funds to cover payment, see R. Bogaert, "Recherches sur la banque en Égypte Gréco-Romaine” (1987), Trapezitica, supra note 64 at 6,23 .
} 
In West Europe, during the early centuries of the Middle Ages,$^{80}$ the economy collapsed and trade was reduced to a trickle. Monetary economy survived only in a rudimentary form ${ }^{81}$ and banks disappeared from the West after the $4^{\text {th }}$ century CE. ${ }^{82}$ Banking services reappeared in Europe in the later part of the Middle Ages to satisfy the growing demands of trade. "Genoa happens to preserve the earliest notarial minute books that have survived (from 1154 on) ... [which] are the first source that contains a fairly large number of documents showing bankers at work." ${ }^{83}$ Deposit banking, in the form of taking deposits and lending out of them in the depositary's own name was reborn in Italy and 'exported' elsewhere ${ }^{84}$ in the course of the $12^{\text {th }}$ and $13^{\text {th }}$ centuries, as part of a commercial revolution that took place as of the $11^{\text {th }}$ century or so. ${ }^{85}$

As originally in Ancient Greece, it was the moneychanger who commenced to take deposits, mix them, and lend out of them. By 1350, in becoming bankers, ${ }^{86}$ moneychangers developed a system of local payments by book transfers, with the view of eliminating "[t]he great inconvenience of making all payments in specie, especially the waste of time involved in counting coin." ${ }^{\prime 7}$ The system that developed was strictly local; no facility for inter-city book transfers is known to have existed throughout the Middle Ages.

Thus, between late $13^{\text {th }}$ and early $14^{\text {th }}$ century the moneychangers of Venice, the campsores, became bankers. ${ }^{88}$ They accepted deposits, lent out of them, and provided book

\footnotetext{
${ }^{80}$ The fall of Rome in 476 CE marks the end of Antiquity and the beginning of the Middle Ages. For Western Europe, the end of the Middle Ages is marked by the discovery of the New World in 1492, or perhaps slightly later, in the early $16^{\text {th }}$ century, by the division of Western Christianity in the Reformation, the rise of humanism in the Italian Renaissance, and the beginnings of European overseas expansion. These propositions are common knowledge. See in general e.g. http://simple.wikipedia.org/wiki/Middle_Ages, accessed 27 December 2017.

${ }^{81}$ Robert S Lopez, "The Dawn of Medieval Banking", in Center for Medieval and Renaissance Studies, University of California, Los Angeles, ed, The Dawn of Modern Banking (New Haven and London: Yale University Press, $1979)$ at 1, 3-5. For payments in kind assessed in monetary value and on occasion supplemented with low-value coins that took place in the Carolingian Empire ( $8^{\text {th }}$ century CE), see e.g. Alexander Murray, Reason and Society in the Middle Ages (Oxford: Clarendon Press, 1978, rep. 2002) at 31-35.

${ }^{82}$ Bogaert, Les Origines, supra note 34 at 163-165.

${ }^{83}$ Lopez, supra note 81 at 10.

${ }^{84}$ See e.g. André-E Sayous, "Les opérations des banquiers Italiens en Italie et aux Foires de Champagne pendant le XIII" siècle" (1932) 170 Revue Historique 1 [Sayous, "banquiers Italiens"]; and M. Prestwich, "Italian Merchants in Late Thirteenth and Early Fourteenth Century England" in Centre for Medieval and Renaissance Studies, University of California, Los Angeles, ed, The Dawn of Modern Banking (New Haven and London: Yale University Press, 1979) at 77.

${ }^{85}$ The revolution occurred in the aftermath of the feudal anarchy of the manorial economy of the Dark Ages. For a detailed discussion on this general context, see Raymond de Roover, "Chapter II: The Organization of Trade", in MM Postan, EE Rich \& E. Miller, eds, The Cambridge Economic History of Europe Volume 3: Economic Organization and Policies in the Middle Ages (London: Cambridge University Press, 1963, rep. 1979) at 42 [de Roover, "The Organization of Trade"].

${ }^{86}$ Raymond de Roover, "New Interpretations of the History of Banking", in Julius Kirshner, ed, Business, Banking, and Economic Thought in Late Medieval and Early Modern Europe: Selected Studies of Raymond de Roover (Chicago and London: University of Chicago Press, 1974, Phoenix Edition 1976) at 213 [de Roover, "New Interpretations"].

${ }^{87}$ See Raymond De Roover, "What is Dry Exchange?" in Julius Kirshner, ed, Business, Banking, and Economic Thought in Late Medieval and Early Modern Europe: Selected Studies of Raymond de Roover (Chicago and London: University of Chicago Press, 1974, Phoenix Edition 1976) 183 at 184 [de Roover, "Dry Exchange"].

${ }^{88}$ Sir William S Holdsworth, A History of English Law, vol 8 (London: Methuen \& Co., Sweet and Maxwell, $2^{\text {nd }}$ ed: 1937, rep. 1966) at 178.
} 
transfer payment services from and to current accounts kept with them. ${ }^{89}$ To eliminate fraud, a book transfer required the attendance of both payer and payee at the bank. ${ }^{90}$ Ultimately, in some cases, the payer's attendance could be dispensed with and the payer's banker was prepared to act on the payer's instruction presented by the payee. The Medieval non-transferable cheque was thus born, as a payment order issued by the payer to the payee instructing the payer's banker to pay to the payee, as well as authorizing the payee to collect from the banker. It was however not widely used. ${ }^{91}$

Bankers held accounts with each other which possibly allowed for intra-city interbank transfers ${ }^{92}$ which may have been settled only on irregular intervals. Each bank kept with it only a fractional reserve, namely, a limited amount of coined money, ready to satisfy an anticipated demand for cash withdrawal; it lent or invested most of the money received on deposit. Availability of payment by book transfers, recognized by early $14^{\text {th }}$ century legislation in Venice, allowed banks to reduce cash holdings and increase their investments and credit extensions.

However, throughout the Continent, during the $15^{\text {th }}$ century, private deposit banks declined. Repeated bank failures undermined the confidence of merchants and further triggered hostility by public authorities. ${ }^{93}$ Together with a chronic shortage of good coins, the increased risk in keeping money with a banker led to a devaluation of "bank money" compared to that of "coined money". ${ }^{94}$ Ultimately, in a process that "did not gain momentum until the last quarter of the sixteenth century," public banks gradually replaced private banks in commercial centres. ${ }^{95}$

\footnotetext{
${ }^{89}$ See in detail: Reinhold Mueller, "The Role of Bank Money in Venice, 1300-1500”, in Fondazione Giorgio Cini et al., eds, Studi veneziani (NS) vol 3 (Pisa: Giardini, 1979) at 47.

${ }^{90}$ De Roover, "New Interpretations", supra note 86 at 215, 216; R. De Roover, L'Evolution de la Lettre de Change $\mathrm{XIV}^{\mathrm{e}}-\mathrm{XVIII}^{\mathrm{e}}$ siècles (Paris: Librairie Armand Colin, 1953) [hereafter: De Roover, lettre de change] at 208. See also at 212-13. In these three pages he summarizes the views of Bartolo Da Sassofferato (1314-1357); Baldo Degli Ubaldi (1327-1400); and Giasone Del Maino (1435-1519). De Roover acknowledges (ibid. at 208) Bartolo's text to be "obscure" but claims to follow its usual interpretation including by the two other jurists. Ibid. at 85-87. See also Usher, Deposit Banking above note 31 at 90, speaking of "the custom of transacting all important business in person if possible" as facilitated by "[t]he compactness of medieval and early modern towns and the concentration of the commercial community..."

${ }^{91}$ See in general, De Roover, "New Interpretations", Ibid. at 216-17 as well as Usher, Deposit Banking above note 31 at 90-94. For an extensive discussion, see M. Spallanzani, "A Note on Florentine Banking in the Renaissance: Orders of Payment and Cheques" (1978), 7:1 Journal of European Economic History 145. The author points out (e.g. at 146) the difficulty in identifying with certainty those payment orders which are cheques. Furthermore, his definition of "cheque" (at 148), as "an order of payment issued on a bank ... by someone who has funds available" is too broad and in effect does not distinguish between cheques and other payment orders. At the same time, my overall impression from the article is that he speaks of a "cheque" in the correct sense.

92 But contrary to Mueller, ibid at 74-76, Mark Manning, Eriend Nier \& Jochen Schanz, eds, The Economics of Large-value Payments and Settlement: Theory and Policy Issues for Central Banks (Oxford: Oxford University Press, 2009) at 24 find "no conclusive evidence" for interbank transfers in Medieval Venice.

${ }^{93}$ De Roover, "New Interpretations" supra note 86 at 219.

${ }^{94}$ Frederic C Lane, Venice A Maritime Republic (Baltimore: John Hopkins University Press, 1973) at 328-29 [Lane, Venice]; for the same phenomenon in Venice at a later period see ibid at 402. See also Frederic C Lane, "Venetian Bankers, 1496-1533: A Study in the Early Stages of Deposit Banking" (1937) 45 Journal of Political Economy 187 at 200-01 [Lane, "Venetian"].

${ }^{95}$ de Roover, "New Interpretations", supra note 86 at 223. For a discussion of the public bank in Venice as a successor of the private bank system that failed primarily due to excessive lending by means of simple book entries, see Charles F Dunbar, "The Bank of Venice" (1892) 6 Quarterly Journal of Economics 308; and Gino Luzzatto, "Les banques publiques de Venise (Siècles XVI-XVIII)" in Johannes Gerard van Dillen, ed, History of the Principal
} 
Heralding this development, Venice gave rise to a "distinctive style" of banking, referred to as giro banking, under which the primary purpose of banks was the making of payments on behalf of customers rather than making loans. ${ }^{96}$ For its part, The Bank of Amsterdam, "established in 1609 under the guarantee of the city, ${ }^{, 97}$ was a leader among the post-Medieval public banks. ${ }^{98}$

During the late Middle Ages, and to accommodate intercity commerce, exchange banking evolved in Continental Europe side by side with deposit banking. ${ }^{99}$ It was practiced by large merchants who lent to exporters located in one market, who in turn sent goods for sale in another market. Repayment was made out of the proceeds of the sale, in the destination market, by the seller's correspondent to the lender's correspondent in that market. ${ }^{100}$ This practice gave rise to the bill of payment, being the predecessor of the bill of exchange. ${ }^{101}$ For their part, exchange bankers formed an intercity network that gave rise to the emergence of an elaborate multilateral clearing and settlement arrangement, implemented by them periodically in medieval fairs. ${ }^{102}$

Public Banks (London: Frank Cass, 1964, being $2^{\text {nd }}$ impression of the $19341^{\text {st }}$ edition, The Hague: Martinus Nijhoff, 1934) at 39.

${ }^{96}$ Lane, Venice supra note 94 at 147. See also Lane, "Venetian" supra note 94 at 187 specifically rejecting earlier such institutions and stating that "Giro banks did not come into existence until the late sixteenth century, at Venice in $1584 . . . "$

${ }^{97}$ Adam Smith, The Wealth of Nations (Chicago: University of Chicago Press, 1976; being the 1776 original text, edited by E. Cannan and prefaced by GJ Stigler, 'Two Volumes in One') vol 1 at 504.

${ }^{98}$ See e.g. Johannes Gerard van Dillen, "The Bank of Amsterdam”, in van Dillen, ed, supra note 95 at 79; Adam Smith, ibid at 503-13; Pit Dehing \& Marjolein C. 't Hart, "Linking the Fortunes: Currency and Banking, 1550-1800" in Marjolein 'T Hart, Joost Jonker \& Jan Luiten van Zanden, eds, A Financial History of the Netherlands (Cambridge: Cambridge University Press, 1997) at 45-51; and Stephen Quinn \& William Roberds, "The Big Problem of Large Bills: The Bank of Amsterdam and the Origins of Central Banking” (2007) [For a former version, see Federal Reserve Bank of Atlanta, Working Papers Series, Working Paper 2005-16, August 2005 (albeit the latter contains lots of econometrics which is inaccessible to a non-specialist such as myself)]. For money and banking in Amsterdam see also Jan De Vries \& An van der Woulde, The First Modern Economy: Success, Failure, and Perseverance of the Dutch Economy, 1500-1815 (Cambridge: Cambridge University Press, 1997) at 81-91 and 12934.

${ }^{99}$ Raymond de Roover, "Banking and Credit in the Formation of Capitalism", Fifth International Conference of Economic History Leningrad 1970 (Paris, 1979) at 9. See in detail, Raymond de Roover, Money, Banking and Credit in Mediaeval Bruges: Italian Merchant Bankers, Lombards and Money Changers: A Study in the Origins of Banking (Cambridge, Mass: The Medieval Academy of America, 1948; republished, London: Routledge/Thoemmes Pres, 1999 as vol. II of The Emergence of International Business, 1200-1800).

${ }^{100}$ For a detailed analysis in a broad context, see de Roover, "The Organization of Trade" supra note 85 at 42.

101 De Roover identifies three stages in the history of the bill of exchange from its inception to the end of the $18^{\text {th }}$ century: De Roover, lettre de change supra note 90 at 18-19. He enumerates two subsequent periods, one of expansion, at the $19^{\text {th }}$ century during which the bill of exchange became discountable, followed by a subsequent contraction in terms of actual use. For the early bill of payment as a notarial instrument, see e.g. André-E Sayous, "L'origine de la lettre de change" (1933) 12 (Ser. 4) Revue historique de droit français et étranger 66; André-E Sayous, "Note sur l'origine de la lettre de change et les débuts de son emploi á Barcelone (XIV e siècle)"'(1934) 13 (Ser. 4) Revue historique de droit français et étranger 315; and André-E Sayous, "Les méthodes commerciales de Barcelone au XVe siècle, d'après des documents inédits de ses archives" (1936)15 (Ser.4) Revue historique de droit français et étranger 255 at 274-86 [Sayous, "méthodes commerciales XV"] at 274-86. With the disappearance of the notarial requirement, the instrument nevertheless retained some formal language: Marie-Thérèse Boyer-Xambeu, Ghislain Deleplace \& Lucien Gillard, Private Money \& Public Currencies: The $16^{\text {th }}$ Century Challenge, translated by Azizeh Azodi (New York and London: ME Sharpe, 1994) at 30.

${ }^{102}$ See Boyer-Xambeu et al., ibid. at 91-94 as well as at 70-91. See also de Roover, lettre de change, supra note 90 at 74-82; Usher, supra note31 at 110-33; and Paul-Louis Huvelin, Essai historique sur le droit des Marchés \& des Foires (Paris: Arthur Rousseau, 1897) at 534-93. 
Against this background the modern banking system, accommodating the present payment system, was born in post-medieval England. Its roots are in the institutional transformation of the goldsmiths' system and the establishment of the Bank of England that followed. ${ }^{103}$

The process involved (i) the transformation of the business of individual goldsmiths into that of deposit bankers who accepted deposits, and lent out of them, including by discounting bills of exchange. As bankers they also facilitated depositors' cheque payments out of and into the deposits; (ii) the existence of a tight network of all such goldsmiths ready to extend credit to each other, so as to allow for reciprocal correspondent banking services. Such services have facilitated interbank debt clearing and settlement, originally on a bilateral and later on a multilateral basis, leading to the establishment of a clearing house. This allowed risk reduction, enhanced efficiency, and the generation of common services that brought upon further development; ${ }^{104}$ (iii) the establishment of the Bank of England, originally as a lender to the government and then, having adopted goldsmiths' practices, gradually evolving in the subsequent two centuries into a modern central bank. As such it maintains settlement accounts for deposit bankers (being the successors of goldsmiths) so as to facilitate interbank final settlement as well as to become a lender of last resort: ${ }^{105}$ and (iv) the issuance of banknotes, first as circulating obligations of goldsmiths evidencing either deposits or loans, then as paper money issued by the goldsmiths, and ultimately, as paper money, 'legal tender', exclusively issued by the Bank of England. ${ }^{106}$

Both correspondent banking and customer payment activity required intensive monitoring by the goldsmith-bankers. In turn, this facilitated credit decision-making and led to specialization in advancing information-intensive non-traded loans. Such lending became a principal niche for a profitable commercial banking business as well as effective financial intermediation for the economy as a whole. In providing such loans, as well as in issuing banknotes and discounting bills of exchange, the goldsmith-bankers came to provide a reliable source of liquidity to the economy.

\footnotetext{
${ }^{103}$ See e.g. Richard D Richards, The Early History of Banking in England (New York: A.M. Kelley, 1965, reprint of 1929 edition). For a succinct summary, see Holdsworth, supra note 88 at 185-92.

${ }^{104}$ See in detail, Stephen Quinn, "Balances and goldsmith-bankers: the co-ordination and control of inter-banker debt clearing in seventeenth-century London", in David Mitchell, ed, Goldsmiths, Silversmiths and Bankers:

Innovation and the Transfer of Skill, 1550 to 1750 (London: Alan Sutton Publishing and Centre for Metropolitan History, 1995) at 53.

${ }^{105}$ See HV Bowen, "The Bank of England During the Long Eighteenth Century, 1694-1820" in Richard Roberts \& David Kynaston, eds, The Bank of England: Money, Power, and Influence 1694-1994 (Oxford: Clarendon Press, 1995). See also Richard D Richards, "The First Fifty Years of the Bank of England (1694-1744)", in van Dillen, ed, supra note 95 at 201; Richard Roberts, "The Bank of England and the City" in Richard Roberts \& David Kynaston, eds, The Bank of England: Money, Power, and Influence 1694-1994 (Oxford: Clarendon Press, $1995)$ at 152, 153. For its origins see also James E Thorold Rogers, The First Nine Years of the Bank of England (Oxford: Clarendon Press, 1887).

${ }^{106}$ Notes of the Bank of England were made legal tender in England and Wales for all payments (except for by the Bank itself) over five pounds by s. 6 of the Bank of England Act, 1833, (U.K.), 3 \& 4 Will. IV, c. 98.
} 
For its part, in departing from the model of the earlier Continental public bank, the Bank of England complemented private commercial banks without competing with or endeavouring to substitute for them. Rather, being their bank maintaining for them accounts, ${ }^{107}$ it became able to furnish them with a source of liquidity so as to be a lender of last resort. As well, it provided them with the efficiency of multilateral settlement in reserve accounts held with it. In both ways, it gradually became as a 'central bank' an integral part of the private bank network. ${ }^{108}$

The banknote was issued first by the goldsmith-banker, ${ }^{109}$ originally possibly as a 'warehouse receipt' for deposited coins, and subsequently against a fractional reserve of coins or metal. ${ }^{110}$ The power to issue banknotes was taken over by the Bank of England, ${ }^{111}$ with convertibility ultimately ceasing to exist altogether in the course of the 20th century. ${ }^{112}$ Using funds on deposit at the central bank, commercial banks buy banknotes from the central bank and sell them for use to the public, against funds held by their customers on deposit with them. As they are exchanged out of and back into deposits "according to customer payment habits," as a form of cash, banknotes (together with coins), are not the principal form of money, a role now preserved to money deposited in banks ${ }^{113}$

The integration of banks into a banking network, consisting of commercial banks multilaterally clearing in a clearinghouse ${ }^{114}$ and settling on the books of the central bank which is an integral part of this network, has led to a fundamental albeit subtle change in the mode of the creation of money through 'banking'. Thus, deposits made to commercial banks are typically not

\footnotetext{
${ }^{107}$ While certainly there was rivalry the fact is that "many goldsmiths opened accounts with the Bank within a few months of its creation"; Holden, supra note 9 at 93.

${ }^{108}$ See e.g. Ben Norman, Rachel Shaw \& George Speight, "The history of interbank settlement arrangements: exploring central banks' role in the payment system” (2011) Bank of England, Working Paper No 412, online: <https://www.ecb.europa.eu/home/pdf/research/Working_Paper_412.pdf>, accessed 27 December 2017.

109 See e.g. Richard D Richards, The Early History of Banking in England (New York: A.M. Kelley, 1965, reprint of 1929 edition) at 40-43 [Richards, Early History]; Holden, supra note 107; Albert Feavearyear, The Pound Sterling: A History of English Money, 2nd ed by EV Morgan (Oxford: Clarendon Press, 1963) at 107-08; JK Horsefield, "The 'Stop of the Exchequer' Re-visited” (1982), 35 Economic History Review 511 at 523 [Horsefield, "Exchequer"]; Tassell and Lee v. Lewis (1695), 1 Ld. Raym. 743 at 744, 91 E.R. 1397 at 1398 (K.B.).

${ }^{110}$ Notes were issued by banks either against deposit of specie, that is, precious metal or coins, or against the negotiation, and hence in discount, of bills of exchange, as well as of promissory notes; Smith, supra note 97; George Tucker, The Theory of Money \& Banks Investigated (New York: AM Kelly, 1964, reprint of 1839 original)at $161,164$.

${ }^{111}$ See e.g. Holden, supra note 107 at 92

${ }^{112}$ Convertibility was abolished for good in the UK under the Gold Standard (Amendment) Act, 1931,21 \& 22 Geo. V, c. 46 .

113 Joseph Huber, “The Chicago Plan (100\% Reserve) and Plain Sovereign Money” (January 2015), online: <http://www.academia.edu/31071041/The_Chicago_Plan_100_Reserve_and_Plain_Sovereign_Money>, accessed 28 December 2017.

${ }^{114}$ For the origins and early history of the London Clearing House see e.g. William Howarth, Our Clearing System and Clearing Houses (London: Effingham Wilson, 1884); and Phillip W Matthews, The Bankers' Clearing House: What it Is and What it Does (London: Pitman \& Sons, 1921). For a modern perspective on the scope of operation of a clearing house, see e.g. Herbert L Baer, Virginia G France \& James T Moser, "What Does a Clearinghouse Do?" (Spring 1995) 1 Derivatives Quarterly 39. See also: James T Moser, "What is multilateral clearing and who cares?" Chicago Fed Letter, Nov. 1994 (No. 87, Federal Reserve Bank of Chicago).
} 
anymore in the form of specie or commodity money. Rather, they are primarily created by lending into customers' deposit accounts. For its part, an addition to bank's liquid assets is typically made not in the form of specie or commodity money, but rather in the form of an increase in the sum credited to that bank's own account; at least for a large bank such increase is in the credit to its account with the central bank. ${ }^{115}$ Other than by receiving an interbank payment, liquidity designed to meet deposit obligations is obtained at least by a large commercial bank, in the form of credit posted to its account with the central bank, through borrowing in an interbank market, selling government securities, or as a last resort, borrowing from the central bank.

At the same time, non-cash payment activity continues to be primarily carried out over deposit accounts held in commercial banks. Monitoring depositors' payment activity in accounts continues to facilitate credit decision-making and lead to specialization in advancing information-intensive non-traded loans, so as to continue to be a principal niche for a profitable commercial banking business as well as effective financial intermediation for the economy as a whole. ${ }^{116}$ This must be true also in an era where credit information may be available from other sources such as credit bureaux.

The architecture, instruments and institutions of the English system spread globally. At present, commercial banks take deposits from the public, lend into customers' deposit accounts, and provide payment services in conjunction with deposit accounts. In each country, at least all major commercial banks clear multilaterally and settle over deposit accounts they hold with the central bank. ${ }^{117}$ They also maintain correspondent relationships ${ }^{118}$ with local small banks as well as with cross-border or overseas large banks, so as to create a global network over which in principle non-cash payments can be made by any account holder to another in any currency. Moreover, as a rule, paper money in the form of banknotes is issued in each country by its central bank.

Banknotes, together with coins for small change, constitute cash (or currency). Payment in cash is typically made face to face, without any intermediation. Noncash payments, whether face to face or between distant parties, require intermediation. Where payer and payee hold their respective accounts with the same bank a noncash payment is carried out by that bank debiting the payer's account and crediting that of the payee. Where payer and payee hold their respective accounts at two banks which are correspondents a noncash payment involves debiting the payer's account by the payer's bank, crediting the payee's account by the payee's bank, and either debiting the account of the payer's bank by the payee's bank or crediting the account of the payee's bank by the payer's bank. In a domestic payment system, at least all major banks hold their accounts with the central bank so that the interbank component of payment between two such banks is carried out as part of the multilateral interbank settlement on the books of the

\footnotetext{
115 See Michael McLeay, Amar Radia and Ryland Thomas, "Quarterly Bulletin 2014 Q1: Money creation in the modern economy” (2014) Bank of England, online: <https://www.monetary.org/wpcontent/uploads/2016/03/money-creation-in-the-modern-economy.pdf>, accessed 27 December 2017.

116 Goodfriend, supra note 32 at 252-57.

${ }^{117}$ CPSS, Core Principles for Systemically Important Payment Systems (Basel: BIS, January 2001) at 34-36, online: <https://www.bis.org/cpmi/publ/d43.pdf>, accessed 27 December 2017.

118 See in general, CPMI, Correspondent Banking (Basel: BIS July 2016) online:

<https://www.bis.org/cpmi/publ/d147.pdf>, accessed 27 December 2017.
} 
central bank. Otherwise, a noncash payment requires a chain of settlements on correspondent accounts, with or without settlement on the books of the central bank, or alternatively, one settlement between correspondent banks followed by another settlement on the books of a central bank. To take a simple example for the latter, the interbank component of a noncash payment in Australian currency from a customer of Bank A in Canada to a customer of Bank B in Australia, assuming that the two are non-correspondent major banks, is carried out by Bank A using its correspondent, another Australian major bank, which in turn, settles with Bank B on the books of the central bank of Australia.

Three principal features characterize payment services facilitated by the modern banking system. First, value held on deposit with participating banks, often referred to as 'bank money' or more specifically, 'commercial-bank money' (or even 'ledger money'), is denominated in and is redeemable to fiat money (or banknotes), that is, an official currency or 'legal tender'. Second, such value is in the form of a claim in an account maintained with a bank. Typically, this is an asset account; however, payment may be made by means of a credit card, in which case payment is carried from the payer's credit account rather than asset account having a positive balance in bank money. Also in such a case, payment results in an increase in the sum of bank money available to the payee in the payee's asset account—while the payer becomes obligated to reimburse the payer's bank, typically (if not exclusively) in bank money (originating from the payer's asset account). Third, claims against the central bank, often referred to as claims to 'central-bank money', are available both to holders of fiat money/banknotes and the banks. ${ }^{119}$ The latter multilaterally settle their reciprocal claims on the books of the central bank. Obligations on bank deposits payable on demand are referred to as 'scriptural money', being a category covering both commercial and central bank money. ${ }^{120}$ In principle, the sum of commercial bank money is a derivative of the sum of central bank money; the former manipulated by the central bank's power to set interest rates through the sale of government securities to banks and/or lending to banks, primarily with the view of achieving price stability. ${ }^{121}$ Gold reserves, which may be assets of a central bank, do not play any explicit role in the creation of the money supply. ${ }^{122}$

The non-cash payment system is then premised on the use of 'scriptural money.' Its architecture is centralized. Thereunder, a bank maintains deposit accounts for customers (who thus keep with it commercial bank money). For its part, a large bank may also maintain deposit accounts (in commercial bank money) for correspondent banks. Finally, the central bank maintains settlement (deposit) accounts at least for large banks (which thus hold with it central

\footnotetext{
${ }^{119}$ For the distinction between 'commercial-bank money' and 'central-bank money' see e.g. Manning, Nier \& Schanz, supra note 92 at 4.

${ }^{120}$ For this term see: Antonio Sáinz de Vicuña, “An Institutional Theory of Money”, in Mario Giovanoli and Diego Devos, eds, International Monetary and Financial Law: The Global Crisis (Oxford: OUP, 2010) at 517 and 527.

${ }^{121}$ See e.g.: Michael McLeay, Amar Radia and Ryland Thomas, "Money in the modern economy: an introduction" BOE Quarterly Bulletin 2014 Q1 at 4; Michael McLeay, Amar Radia and Ryland Thomas, "Money in the modern economy" BOE Quarterly Bulletin 2014 Q1 at 14; and B. Friedman, "The Future of Monetary Policy: The Central Bank as an Army with Only a Signal Corps?” 2:3 International Finance 261, (1999).

${ }^{122}$ For their function, see e.g. Ronan Manly, Why the World's Central Banks hold Gold - In their Own Words, posted on March 20, 2018 https://www.bullionstar.com/blogs/ronan-manly/worlds-central-banks-hold-gold-words/, visited October 5, 2018
} 
bank money). ${ }^{123}$ As a whole, the system can be visualized as a pyramid at whose head or apex stands the central bank with which at least large banks hold accounts, and possibly with small banks holding accounts with large banks. Individual and corporate customers are at the bottom or base of the pyramid holding their accounts in banks (whether large or small). ${ }^{124}$

\section{The coming of the cyber age: Electronic payments, e-money, and access to central bank balances}

\section{The advent of electronic banking and e-money}

Historically, payment instructions accessing bank money were either oral or, more typically, in writing. Use of telecommunication, first the telegraph and then the transatlantic cable, goes back to mid- $19^{\text {th }}$ century. ${ }^{125}$ However, the watershed of electronic banking, where payments are processed as well as transmitted electronically, is a development of the second part of the $20^{\text {th }}$ century. Once it became possible to transmit instructions from a computer or computer terminal, the electronic funds transfer was born. Telecommunication in the electronic age was originally on cable or wire ${ }^{126}$ subsequently the wireless option became available, ${ }^{127}$ and ultimately, instructions could be transmitted over the Internet. ${ }^{128}$

Security in electronic funds transfer has been implemented by the physical protection of network components ${ }^{129}$ and more recently by the introduction of tamper-resistant access devices and cryptographic data protection. Broadly speaking, 'cryptography' (literally: secret writing) denotes "a method of storing and transmitting data in a particular form so that only those for

${ }^{123}$ On moving away from this tiering structure see e.g. Evangelos Benos, Gerardo Ferrara and Pedro Gurrola-Perez, "The impact of de-tiering in the United Kingdom's large-value payment system" (2017) Bank of England, Working Paper No 676.

${ }^{124}$ See e.g. E Gerald Corrigan, "Luncheon Address: Perspectives on Payment System Risk Reduction”, in David B.Humphrey, ed, The U.S. Payment System: Efficiency, Risk and the Role of the Federal Reserve (Boston: Kluwer Academic Publishers, 1990) at 129-130. See also Hans J Blommestein \& Bruce J Summers, "Banking and the Payment System”, in Bruce J Summers, ed, The Payment System: Design, Management and Supervision (Washington: International Monetary Fund, 1994) at 15 and 27; and Bruce J Summers, "The Payment System in a Market Economy", in Summers, ibid, at 1-5.

${ }^{125}$ See Douglas W Arner, Janos N Barberis \& Ross B Buckley, "The Evolution of Fintech: A New Post-Crisis Paradigm?" at 4, online: <https://papers.ssrn.com/sol3/papers.cfm?abstract_id=2676553>, accessed 28 December 2017.

${ }^{126}$ For an early discussion on the subject see Israel Sendrovic, "Technology and the Payment System", in Summers, supra note 124 at 178 .

127 See Gianni Bonaiuti, "Economic Issues on M-Payments and Bitcoin” in Gabriella Gimigliano, ed, Bitcoin and Mobile Payments Constructing a European Union Framework (London: Palgrave, 2016) at 27.

${ }^{128}$ See CPSS, Innovations in retail payments (Basel: NIS, May 2012), online:

<https://www.bis.org/cpmi/publ/d102.pdf>, accessed 27 December 2017. See also: CPSS, Survey of developments in electronic money and internet and mobile payments (Basel: BIS, March 2004), online:

<https://www.bis.org/cpmi/publ/d62.pdf>, accessed 27 December 2017.

${ }^{129}$ Gideon Samid, Tethered Money: Managing Digital Currency Transactions (London: Academic Press, 2015) at 80-81. 
whom it is intended can read and process it." ${ }^{130}$ Strictly speaking, the term points at a specific method to that end, under which "complexity ... is injected into data so that only those who possess a key ... can remove the complexity ... and understand the intended message, while those without the key will not be able to retrieve the hidden message in a timely manner." The "process of applying cryptography to a message so that only its intended readers can understand it" is called 'encryption'; the reverse, namely the "process of using a ... key to recover the intended message from its encrypted form," is called 'decryption.' Where the sender and receiver of a cryptographic message "share the same key data or mutually deducible key data," encryption is 'symmetric'. Otherwise, where they do not share the same key data, encryption is said to be 'asymmetric'. Either way secrecy is achieved by means of the application of mathematical theories. Cryptographic complexity addresses factors relating to the decryption of the message and its result. ${ }^{131}$ Security is enhanced by the use of random data ${ }^{132}$ to generate keys, since "patterns could be recognized [and] could aid in a brute-force attack." ${ }^{133}$ Looking ahead, security will be enhanced by the use of 'quantum data,' namely, data 'marked' by merely being observed so as to alert the ultimate (designated) recipient to the fact that communication had been intercepted. ${ }^{134}$

Developments exploiting such technological achievements have not been limited to communication. It became also possible to 'load' monetary value (that is, value denominated in an official or, in fact, any unit of account) on a tamper-resistant stored-value device such as a card or personal computer. In such a case, the value became known as 'electronic money' or ' $e$ money'. The majority of e-money schemes have involved "balance-based" products. In such products, devices store and manipulate a numeric ledger, with transactions performed as debits or credits to a balance. Accordingly, this type of e-money is a monetary balance or value recorded electronically on and is available from a stored-value product (SVP), such as a chips card, or a hard drive in a personal computer, or a server. ${ }^{135}$ Such a record, accessible from the device without resort to the bank's computer system, can be viewed as a decentralized bank account. ${ }^{136}$ E-money is said to "differ ... from so-called access products, which are products that allow consumers to use electronic means of communication to access otherwise conventional payment services" in and out bank accounts. ${ }^{137}$

\footnotetext{
${ }^{130}$ See definition of “cryptography” online: <http://searchsoftwarequality.techtarget.com/definition/cryptography>, accessed 28 December 2017.

${ }^{131}$ For definition of "cryptographic complexity" (as well as “cryptographic equivocation”), see Samid, supra note 188 at $139-40$ (Glossary).

${ }^{132}$ For the superior protection of randomness premised on "a cipher which use[s] no mathematical complexity but instead call[s] for large amounts of randomness" see e.g. Carsten Stöcker and Gideon Samid, "Randomness: The Fix for Today’s Broken Security", online: <https://medium.com/@cstoecker/randomness-the-fix-for-todays-brokensecurity-39ea7dc3a89b>, accessed 9 January 2018.

${ }^{133}$ CPSS and the Group of Computer Experts of the central banks of the Group of Ten countries Security of electronic money (Basle: BIS, 1996) at 16,, online: 〈https://www.bis.org/cpmi/publ/d18.pdf>, accessed 27 December 2017. A brute-force attack occurs when "An outsider could try to discover the plaintext by testing all possible decryption keys." Ibid. at 58.

${ }^{134}$ Samid supra note 129 at 106.

135 CPSS, Security supra note 133 particularly at 5. See also information on 'electronic money' at <https://en.wikipedia.org/wiki/Electronic_money>, accessed 27 December 2017.

136 Alan L Tyree, "The Legal Nature of Electronic Money" 10 Journal of Banking and Finance Law and Practice 273 at 276 (1999).

${ }^{137}$ CPSS, Implications for Central Banks of the development of electronic Money (Basle, October 1996) at 1 emphasis in the original; online: https://www.bis.org/publ/bisp01.pdf , accessed October 07, 2018.
} 
A minority of e-money products may still operate on devices that store electronic "notes" (sometimes called coins or tokens) that are uniquely identified by a serial number and are associated with a fixed, unchangeable denomination. In such a "note-based" model, transactions are performed by transferring notes from one device to another, and the balance of funds stored on a device is thus the sum of the denominations of all notes on the device. However, as in the "balance-based" products, transferability is typically restricted, and consumer cardholders may usually make payments only to merchants who may clear these payments or deposit the accumulated balances exclusively through their acquiring banks. ${ }^{138}$ Such a product provides the link between traditional value-transfer systems to innovative circulating digital coins discussed in Part V.

Under a variant of a "balance-based" e-money product, monetary value is not loaded on the device; rather, it is available from a master account, belonging to the issuer or someone acting on the issuer's behalf. ${ }^{139}$ As in the case of e-money, monetary value is not available from the payer-debtor's own bank account. ${ }^{140}$ However, such prepaid value is in a bank account, even if not that of the payer. Its use entails communication to the issuer and requires the cardholder to access a bank account (even if not his or hers). From this perspective, a prepaid product device is more a variant of an access device rather than of an SVP.

According to Crawford, e-money is truly 'money' when it may circulate from one person to another, that is, from one SVP to another, without being 'cleared' or intermediated by the issuer. ${ }^{141}$ This seems to me to be true for both "balance-based" and "note-based" e-money products. However, upon reflection also, e-money, in all its manifestations, is ultimately a variant of 'bank money', ${ }^{142}$ thus, whether e-money is purchased in cash or by means of a debit to the purchaser's bank account, the issuer has its own bank account credited with the amount sold to the purchaser. Where the e-money is purchased from a bank the account credited is the reserve account of the selling bank. Payment in e-money is forwarded to the payee's bank which credits the payee's account with the amount of payment and forwards the e-money itself for redemption against the value previously credited to the seller's account. In the final analysis, even where prepaid value or e-money is not issued by a bank, a scheme must facilitate the purchase and redemption through banks.

'Electronic banking' enhanced payment services in several other ways. First, it

\footnotetext{
${ }^{138}$ CPSS, Security supra note 133 particularly at 5.
}

${ }^{139}$ For the view that this is in fact e-money in the true sense, see: Nadia F. Piffaretti, A Theoretical Approach to Electronic Money (February 1998). FSES-302. Available at SSRN: https://ssrn.com/abstract=70793 or http://dx.doi.org/10.2139/ssrn.70793

${ }^{140}$ Unfortunately, the confusion between these two types of payment products is rampant. For a definition of 'emoney' that does not include the prepaid product, see Ben Fung, Miguel Molico and Gerald Stuber, "Electronic Money and Payments: Recent Developments and Issues" (2014) Bank of Canada Discussion Paper 2014-2, online: <http://www.bankofcanada.ca/wp-content/uploads/2014/04/dp2014-2.pdf>, accessed 27 December 2017.

${ }^{141}$ Bradley Crawford, "Is Electronic Money Really Money?” (1997), 12 Banking and Finance Law Review 399.

${ }^{142}$ I am thus not persuaded by the classification of CPMI, Digital Currencies (Basel: BIS, November 2015) at 6, online: https://www.bis.org/cpmi/publ/d137.pdf, accessed 11 March 2018, under which e-money is lumped with digital currencies as "E-money (broad sense)" so as to be contrasted with commercial bank money. 
introduced electronic processing also to paper-based instruments such as cheques. ${ }^{143}$ Second, it facilitated new as well as variations of existing products. ${ }^{144}$ Third, new players, such as money transmitters ${ }^{145}$ or payment institutions, ${ }^{146}$ and e-money institutions ${ }^{147}$ entered the scene as endpayment institutions in a payment transaction, facilitating domestic and international payments in small amounts to parties who do not have bank accounts. Fourth, the power balance in the partnership between financial institutions and telecommunication carriers has shifted, allowing the latter a greater voice and share in the payment market. ${ }^{148}$ Fifth, in facilitating instant communication, electronic banking allowed the use of risk reduction methods as well as instant authorization leading to an immediate final credit to the payee's account way ahead of the interbank settlement; such may be the case in domestic large value wholesale payment systems ${ }^{149}$, and retail fast payments networks. ${ }^{150}$ This is also the case in a typical credit card payment, even when it is carried internationally. ${ }^{151}$

Electronic banking facilitated branchless banking to the detriment of banks with a large

${ }^{143}$ See in general e.g. Benjamin Geva, "Is Death of the Paper Cheque Upon Us? The Electronic Presentment and
Deposit of Cheques in Canada" (2014) 30 BFLR 113; and Benjamin Geva, "From Paper to Electronic Order: The
Digitalization of the Check in the USA" (2015) 4 Penn State Journal of Law and International Affairs 96.
${ }^{144}$ Such as preauthorized debits ('PADs') replacing the delivery of a series of post dated cheques; the debit card
complementing the credit card and to a large extent substituting both cash and cheques; preauthorized credits
('PAPs') substituting paycheques.
145 See e.g. Section 102 (14) of the Uniform Money Services Act (UMSA), online:
<http://www.uniformlaws.org/shared/docs/money\%20services/umsa_final04.pdf>, accessed 28 December 2017 ,
under which "Money transmission" is defined to mean "selling or issuing payment instruments, stored value, or
receiving money or monetary value for transmission..."
146 Defined in Article 4 (4) of the Directive (EU) 2015/2366 of the European Parliament and of the Council of 25 November 2015 on payment services in the internal market, amending Directives 2002/65/EC, 2009/110/EC and 2013/36/EU and Regulation (EU) No 1093/2010, and repealing Directive 2007/64/EC, Official Journal of the European Union 23.12. 2015, L 337/35, online: <http://eur-lex.europa.eu/legalcontent/EN/TXT/?uri=celex:32015L2366>, accessed 28 December 2017 to mean: "a legal person that has been granted authorisation in accordance with Article 11 to provide and execute payment services throughout the [European] Union." The term does not include credit institution (bank), electronic money institution, or post office giro institutions. See Article 1(1).

${ }^{147}$ Defined under Article 2(1) of the DIRECTIVE 2009/110/EC of the European Parliament and of the Council of 16 September 2009 on the taking up, pursuit and prudential supervision of the business of electronic money institutions amending Directives 2005/60/EC and 2006/48/EC repealing Directive 2000/46/EC, Official Journal of the European Union, 10.10. 2009. L 267/7, online: <http://eurlex.europa.eu/legal-

content/EN/TXT/?uri=CELEX\%3A32009L0110>, accessed 27 December 2017, to mean: "a person that has been granted authorisation under Title II to issue electronic money."

${ }^{148}$ See e.g. document issued by the Canadian Bankers Association (CBA), Canadian NFC Mobile Payments Reference Model, Version 1.03, 14 May 2012, online:

<https://www.cba.ca/Assets/CBA/Files/Article\%20Category/PDF/msc_20120514_mobile_en.pdf>, accessed 28 December 2017

\footnotetext{
${ }^{149}$ See e.g. the large value wholesale payment system in Canada where finality of payment is guaranteed by the central bank prior to the completion of settlement. CPSS, Core Principles, supra note 117 at 30, online: <https://www.bis.org/cpmi/publ/d43.pdf>, accessed 28 December 2017.

${ }^{150}$ See e.g. CPMI, Fast payments -Enhancing the speed and availability of retail payments (Basel: BIS, November 2016), online: <https://www.bis.org/cpmi/publ/d154.pdf>, accessed 28 December 2017.

${ }^{151}$ For the legal nature of the credit card payment see in general: Benjamin Geva, "The Processor and the Contractual Matrix in a Card Scheme: How Privity Fell and Resurrected in Aldo v. Moneris" (October 2013) $32: 5$ Nat'l Banking L Rev 73.
} 
branch network. ${ }^{152}$ As well, possible impact of electronic banking on monetary policy has been fiercely debated. ${ }^{153}$ At the same time, none of the various facets of electronic banking has affected the architecture of the payment system even as it expanded its scope and globalized it. No wonder, the law governing wireless instructions is the same as the one governing wire orders. ${ }^{154}$ For their part, money transmitters, payment institutions as well as e-money institutions have been using banks as intermediaries in the transfers in which they participate at either end of the transaction. ${ }^{155}$ They thus increased rather than decreased payment intermediation.

Furthermore, not treating such institutions as deposit takers hinges on a 'benevolent' strict view of 'deposit taking' so as to exclude the delivery of money for a specific purpose. ${ }^{156}$ True, a payment instruction issued from a digital device such as a mobile phone rather than from a computer terminal or computer is often said to result in a mobile payment. When the payment scheme is operated over mobile devices it is even described as involving 'mobile money'. However, in substance, payment orders initiated from a digital or mobile device is a specie of an electronic funds transfer. ${ }^{157}$ For its part 'mobile money' is a form of 'e-money'. It is therefore confusing to treat such developments as reflecting a "digitization of state-issue currenc[y]" even in connection with an on-line (e-commerce) transaction. ${ }^{158}$ Ultimately, efficiency is bound either to turn payment institutions into banks or for banks take over payment institutions, either directly or as subsidiaries, so as to eliminate this unnecessary layer of intermediation. The issue for banks is the adoption of a different level of service rather than the elimination of banks as an essential component in linking between payers and payees.

The broader question however is whether 'electronic banking' has not been superseded by 'Fintech,' 'snatching' money and payments from the banking system. Fintech refers to the use

\footnotetext{
${ }^{152}$ Hanno Beck, "Banking is essential, banks are not. The future of financial intermediation in the age of the Internet” (2001) 3:7-22 Economic Research and Electronic Networking, online: <https://link.springer.com/content/pdf/10.1023\%2FA\%3A1009927623530.pdf>, accessed 9 January 2018.

${ }^{153}$ See e.g. Benjamin J Cohen, “Electronic money: New day or false dawn?” (2001) 8:2 Review of International Political Economy 197, online:

<https://www.researchgate.net/publication/233010154_Electronic_money_New_day_or_false_dawn>, accessed 9 January 2018.

154 See e.g. Benjamin Geva, “The Wireless Wire: Do M-Payments and UNCITRAL Model Law on International Credit Transfers Match?” (2011) 27:2 BFLR 249.

155 See e.g. CPSS and the World Bank, General principles for international remittance services (Basel: BIS and the World Bank, January 2007), online: 〈https://www.bis.org/cpmi/publ/d76.pdf〉, accessed 28 December 2017.

${ }^{156}$ For a critical analysis see e.g. Benjamin Geva and Muharem Kianief, "Reimagining E-Money: Its Conceptual Unity with Other Retail Payment Systems" (2005) 3 Current Developments in Monetary and Financial Law 669 and 677-79.

${ }^{157}$ Whether from (or into) an asset account, credit line, or stored-value — as the case may be.

${ }^{158}$ Notwithstanding Joshua S. Gans and Hanna Halaburda, "Some Economics of Private Digital Currency" (2013)

Bank of Canada, Working Paper 2013-38, online: <http://www.bankofcanada.ca/wp-

content/uploads/2013/11/wp2013-38.pdf>, accessed 28 December 2017.
} 
of technology by IT firms ${ }^{159}$ to deliver financial solutions directly to purchasers of financial products such as payment services. ${ }^{160}$ Technology designed to deliver financial solutions is however available also to banks whether directly or indirectly by purchase from IT firms. Alternatively, IT firms may become banks and compete with existing banks on equal footing. It is not that 'banking' survives while banks die; ${ }^{161}$ rather, as an economic model banking has adopted new technologies to be used by old and new types of institutions. Whether and to what extent this remains true in light of subsequent developments is discussed further below.

\section{(ii) Availability of central bank account balances and their equivalents to the public}

In reviewing the present architecture of the payment system prior to the Fintech era Goodfriend opined that “... although valuing deposits at par and holding fractional reserves is efficient for individual banks, it had the potential for generating destabilizing systemwide bank runs." In his view this risk is however "remedied efficiently by central bank monetary policy,"162 as well as by other payment system policies. ${ }^{163}$ Conversely, reviving and building on old ideas, ${ }^{164}$ a recent set of proposals will make central bank money deposits available to the public either directly or indirectly. ${ }^{165}$ A typical rationale, premised on new technological developments, is that:

Central banking evolved at a time when service provision in local branches was integral to providing banking services. In that world it made sense for the central bank to 'wholesale' its core exchange settlement and liquidity support services to banks which would then 'retail' them to individuals and businesses via their branches, passbooks and cheque accounts. It was impracticable for central banks' services to be provided to individuals.

At the same time, the rationale goes on, "[m]odern technology enables us to extend some core central banking services to individuals and businesses." 166 As a matter of history, the argument is doubtful, as post Medieval public banks, discussed in Part III(ii) above, 'retailed' their services to the public. At the same time, it is true that with the increase in the size and geographical scope

\footnotetext{
${ }^{159}$ Generally speaking, IT “deals with the technology part of any information system, and as such deals with hardware, servers, operating systems and software etc." See e.g. <http://www.differencebetween.com/difference-betweeninformation-systems-and-vs-information-technology/>, accessed 28 December 2017.
}

${ }^{160}$ A broader definition under which Fintech "refers to the use of technology to deliver financial solutions", as in at 6 , will encompass the use of technology by banks such as in electronic banking, and hence is unhelpful for the purposes of this paper.

${ }^{161}$ As claimed by "clever consultants" according to "Unresolved," the Economist September 8 ${ }^{\text {th }}, 2018.20$ at 21.

162 Goodfriend supra note 32 at 248.

163 Goodfreind, ibid at 261.

${ }^{164}$ For detailed discussions see references in sources cited in notes 171 and 172 infra.

${ }^{165}$ Unfortunately it has become common to treat such a proposal as relating to central bank digital currency. See e.g. see Michael D Bordo and Andrew T Levin, "Central Bank Digital Currency and the Future of Monetary Policy" (2017) NBER, Working Paper 23711, online: <http://www.nber.org/papers/w23711>, accessed 28 December 2017. Digital currencies (in the true sense of the term) are discussed in Part V infra.

166 Nick Gruen, Central Banking for all: A Modest Proposal for Radical Change (London: Nesta, March 2014) at 7, online: https://www.nesta.org.uk/sites/default/files/central_banking_for_all.pdf, accessed 28 December 2017. 
of the bank customer base, a centralized system is workable only in an enhanced technology environment. Hence, banking-centralization proposals merit consideration.

One proposal premised on this rationale is the provision of payment services to the public exclusively by a designate government agency that will take deposits from the public but will have restricted investment powers so as to be able to invest only in safe assets such as supercollateralized real estate mortgages. Under that proposal, payment transactions will be carried out over deposit accounts with respect to which the liability of the depositary (the government agency) is effectively secured by investment in high quality assets. On this basis, such deposits will benefit from unlimited guarantee of the central bank. Under that proposal, commercial banks will be able to lend to customers and sell them investment products but be precluded from providing payment services. ${ }^{167}$

However, one may reasonably suppose that in upsetting the delicate balance between the roles of the public and private sectors in the monetary and payment systems, this proposal will be perceived as going too far (or in fact, nowhere). Certainly, in monopolizing payment services in the hands of a government agency, the proposal will stifle competition and give no incentive to innovate. Furthermore, the proposal is not persuasive in mandating central bank guarantee on the top of the requirement to invest deposited funds in safe assets. I therefore doubt that in a capitalist economy that proposal will persuade policy makers. At the same time, unclothing it from these objectionable elements, the proposal is a reminiscent of an earlier idea, that of 'narrow banking'; thereunder payment transactions are carried out over bank deposits of which the proceeds are invested in safe assets. ${ }^{168}$ 'Narrow banking' does not require the superimposition of central bank guarantee and in fact does not alter the traditional roles of commercial banks as deposit takers, providers of payment services, and lenders.

Under another proposal the central bank will open accounts and offer payment services directly to the public. This proposal is however said to impose "a large administrative burden" on the central bank that "could distract it from its other functions in [regulating] and managing monetary policy." It is further acknowledged that under the proposal the central bank, "a stateowned enterprise," would undertake pure market functions, in which it "would have no commercial incentive to innovate [payment] services." 169 To meet these objections, under a variant, it is proposed that public access to scriptural central bank money or its equivalent will be indirect. $^{170}$

\footnotetext{
${ }^{167}$ Ibid, passim. In the UK, he designates the National Savings and Investments (NS\&I) as the appropriate governmental agency. At the moment the NS\&I accepts deposits from the public (up to prescribed ceilings) and places them in savings accounts from which payment services cannot be provided. In Gruen's words, "what is being proposed is to allow super-collateralised loans to be treated as part of the monetary system rather than the financial system." Ibid at 9.

168 The term is said to be coined by Robert Litan, What Should Banks Do? (Washington, DC: Brookings Institution, 2005). See Patrizio Lainà, "Proposals for Full-Reserve Banking: A Historical Survey from David Ricardo to Martin Wolf", Economic Thought 4:2 (2015) at 12, online: <http://et.worldeconomicsassociation.org/files/WEA-ET-4-2Laina.pdf>, accessed 28 December 2017. Litan discusses 'narrow banking' ibid at 6, 169-178 and 186-87.

${ }^{169}$ Ben Dyson \& Graham Hodgson, Digital Cash: Why Central Banks Should Start Issuing Electronic Money (London: Positive Money, 2016) at 15, online: <http://positivemoney.org/wpcontent/uploads/2016/01/Digital_Cash_WebPrintReady_20160113.pdf>, accessed 28 December 2017.

${ }^{170}$ Dyson and Hodgson, ibid at 16.
} 
There are however two alternative approaches to such a variant. One is premised on 'full reserve banking' ${ }^{171}$ while the other is of 'plain sovereign money' ${ }^{172}$ Briefly stated, under the former, the entire quantity of commercial bank money, namely, the total amount of demand deposits with banks, is to be backed by $100 \%$ reserve of central bank money held by commercial banks on deposit with the central bank. ${ }^{173}$

Under the latter, that of "plain sovereign money,' ${ }^{174}$ the distinction between the two types of scriptural money is abolished; what exists is only one category of scriptural money, central bank money. ${ }^{175}$ It will be available to members of the public in accounts on the books of the central bank; unless operated by the central bank itself, as discussed above, such accounts will be operated through and managed by commercial banks, ${ }^{176}$ possibly in 'transaction accounts' 177 which will be distinguished from 'investment accounts' of which funds may be invested in designated collections of assets of a broadly similar risk profile. Each investment fund will be a distinct legal and corporate entity. Lending will be carried out of investment funds (possibly as well as from long-term borrowing from the public) and should not create additional money or purchasing power. ${ }^{178}$ Investment account holders will bear the risk of non-payment on due date, and not being available to them prior to that, sovereign money owed to them will not serve as commercial bank money. Rather, prior to maturity on the investment account, sovereign money deposited in them will be lent by the bank and thus will exclusively be used by borrowers from the bank. ${ }^{179}$ Banking will thus fully reclaim its function as an intermediation between savers and borrowers.

\footnotetext{
${ }^{171}$ See e.g. Jaromir Benes and Michael Kumhof, "The Chicago Plan Revisited" (2012) International Monetary Fund, Working Paper WP/12/202, online: 〈https://www.imf.org/external/pubs/ft/wp/2012/wp12202.pdf>, accessed 28 December 2017; William R Allen, "Irving Fisher and the 100 Percent Reserve Proposal" (1993) 36:2 Journal of Law and Economics 703, online: <http://www.journals.uchicago.edu/doi/pdfplus/10.1086/467295>, accessed 28 December 2017; and Lainà, supra note 168.

${ }^{172}$ See e.g.: Huber, supra note 113; Phillipe Bacchetta, The Sovereign Money Initiative in Switzerland: An Economic Assessment (26 September 2017), online: <https://people.unil.ch/philippebacchetta/files/2017/06/Vollgeld_5.pdf>, accessed 28 December 2017. For a blueprint see Ben Dyson, Graham Hodgson \& Frank van Lerven, Sovereign Money - An Introduction (London: Positive Money, 2016), online: <http://positivemoney.org/wpcontent/uploads/2016/12/SovereignMoney-AnIntroduction-20161214.pdf>, accessed 28 December 2017.

${ }^{173}$ There are at least two variants as to the rules which will govern the conduct of monetary policy under such a regime, particularly as to the role of discretion by the central bank. For a summary see Huber, supra note 113 at 3. ${ }^{174}$ Beware of inconsistent use of terminology. Andrew Jackson, Sovereign Money - paving the way for a sustainable recovery (London: Positive Money, November 2013), online: <https://positivemoney.org/wpcontent/uploads/2013/11/Sovereign-Money-Final-Web.pdf>, accessed 28 December 2017, uses the term to denote central bank money distributed directly to business to fund infrastructure projects.

${ }^{175}$ However, it does not make sense to me to have a hybrid system under which scriptural money is available to the public in both commercial and central bank money as I read Dyson \& Hodgson supra note 169 at 28-30 to suggest.

${ }^{176}$ For a precedent from Sri Lanka, albeit for investors' securities accounts operated by intermediaries on the books of the central bank, see Payment \& Settlement Systems Act, No. 28 of 2005, Chapter II Securities Accounts (Secs 610), online: 〈http://www.cbsl.gov.lk/pics_n_docs/09_lr/_docs/acts/Paymt_\&_setmt_sys_act.pdf>, accessed 28 December 2017.

${ }^{177}$ For these two options see Bordo and Andrew Levin, supra note 165.

${ }^{178}$ Where required to meet demand further, lending may be done by the creation of new money by the central bank to be lent to banks and other lending institutions for the purposes of relending it to borrowers in the real economy. See Dyson, Hodgson \& van Lerven, supra note 172 at 36.

${ }^{179}$ Legally of course on maturity of the investment account the bank will be liable to depositors and investors regardless of possible default by borrowers, in which case it will be up to the bank to find sovereign money from other sources to fund its liability to depositors and investors.
} 
Under both approaches commercial banks will cease to create money by lending into customers' deposits. Money creation will be under the exclusive power of the central bank ${ }^{180}$ with commercial banks either being limited to issue its 'replication' or 'shadow' to the public, but not expand its quantity (under the full reserve banking alternative), or being restrained from issuing it at all (under the plain sovereign money alternative). ${ }^{181}$ They will however be able to lend and provide payment services.

An analysis of the pros and cons of each alternative, vis-à-vis each other as well as by reference to the current fractional reserve regime, is beyond the scope of this paper as well as of the competence of this author. At the same time, in relation to the topic at hand, under both alternative banks will continue to accept deposits, make loans (albeit not out of demand deposits), and provide payment services. For sure, they may face competition from 'payment institutions' that do not provide 'investment accounts' services as well as lenders providing 'investment accounts' but not 'payment accounts.' However, it is reasonable to expect that such competitors will be regulated, respectively on the payment, and saving and lending sides, so it will be for banks to leverage the combined services they give to their advantage. For example, as now, monitoring the payment activity of a customer will help a bank in making its lending decision regarding that customer. Hence, a reform under any of these lines will not change the role of commercial banks in the paymengvt system.

What may however change is the legal underpinning of the bank's liability for money deposited in the payments or transactions account. At the moment, a bank is liable to a depositor on a simple debt since money deposited belongs to the bank which can use it as it wishes. ${ }^{182}$ Conversely, under a 'full reserve banking' scheme, the bank's obligation may be conceptualized by analogy to that of a securities intermediary that under Article 8 of the Uniform Commercial Code in the United States ${ }^{183}$ as well as under the Uniform Securities Transactions Act in Canada. ${ }^{184}$ According to this legislation, under the 'indirect holding' regime, a securities intermediary is liable to an investor on a 'securities entitlement' against which the securities

\footnotetext{
${ }^{180}$ In connection with sovereign money see e.g. Dyson, Hodgson and van Lerven, supra note 172 at 28-37. One proposal for full reserve banking is for the central bank to act as a 'currency board' in issuing new money only against a basket of available assets (of which gold is only one); see Warren Coats, "My Political Platform for the Nation - 2017" (31 December 2016), Warren's space (blog), online:

<https://wcoats.wordpress.com/2016/12/31/my-political-platform-for-the-nation-2017/>, accessed 28 December 2017 (see section on Monetary and Financial Policies); Warren Coats, "Real SDR Currency Board" (2011) 22:2 Central Banking Journal, online: <https://works.bepress.com/warren_coats/25/ ${ }^{181}$ For the view that "both logically and according to the International Accounting Standards, sovereign money cannot be considered to be a debt of the state. Instead, sovereign money conforms to the classification of equity," see Ben Dyson \& Graham Hodgson, Accounting for Sovereign Money: Why State-Issued Money is Not 'Debt' (London: Positive Money, 2016) at 9, online: <http://positivemoney.org/wpcontent/uploads/2016/03/AccountingForSovereignMoney_20160309.pdf>, accessed 28 December 2017.

182 The locus classicus for this proposition is Foley v. Hill (1848), 2 HLC 28, 9 ER 1002.

${ }^{183}$ See Uniform Commercial Code (UCC) Article 8 (1994) Sections 8-501 to 8-511, in conjunction with definitions in Section 8-102, online: <https://www.law.cornell.edu/ucc/8>, accessed 28 December 2017.

${ }^{184}$ See Uniform Securities Transfer Act (USTA) (2004), Sections 106-116 in conjunction with definitions in Section 1, online: <https://www.ulcc.ca/en/uniform-acts-new-order/current-uniform-acts/761-securities-transfer/2049secbities-transfer-act>, accessed 28 December 2017.
} 
intermediary must maintain $100 \%$ 'financial asset'. ${ }^{185}$ At the same time, under a 'plain sovereign money' regime the customers will be entitled from their banks under an 'irregular deposit' which envisages a claim premised on an unidentified portion of a mixture of fungible assets (e.g. money) to which ownership passed to the depositary from the various depositors. ${ }^{186}$

In the final analysis, technological feasibility does not necessarily lead to economic justification. For example, as pointed out at the beginning of this section, albeit ahead of Fintech, Goodfriend was on record highlighting the public's substantial efficiency gains of the fractional reserve at the cost of accepted risks, which are anyway mitigated by monetary policy, central bank lending and deposit insurance. ${ }^{187}$ To say the least, under the present system, banks are able to share with customers profit realized from lending out of demand deposits; the chance is that, in a regime under which scriptural central bank money is available to the public in any form, payment services will be more costly. Whether and to what extent gains in safety outweigh efficiency losses may be in the eyes of the beholder. This Section should be taken as outlining banks' continued role and relative advantage in a central bank scriptural money environment rather than necessarily to unequivocally support such a regime.

\section{Cryptocurrencies: heralding a new form of money and payment disintermediation?}

Innovations discussed above were accessing accounts and transacting digitally, expressing value on the screen of a digital device, storing value in an SVP so as to give rise of emoney, and making central bank money or its equivalent available to the public. All have not changed the nature of an interbank transfer as a transfer of scriptural money in the form of a balance of monetary value. Nor have they changed the role of the bank as a payment intermediary.

This does not appear to be the case with the emergence of digital currencies. Very much like an electronic payment instruction, a digital coin consists of encrypted data expressed in strings of bits. However, as "an entity that amounts to a string of bits," a coin 's string have a numerical value as well as a unique identity. ${ }^{188}$ Like physical coins and banknotes, digital coins are not paid out of bank accounts so that their payment does not appear to require intermediation. And yet exactly as the electronic funds transfers they are paid with over the cyber space.

The ensuing discussion excludes currencies not linked to the real economy ${ }^{189}$ and is limited to

\footnotetext{
185 See in general e.g. Benjamin Geva, "Securities Transfers in the Indirect Holding System - Law Reform in Canada in the Footsteps of UCC Article 8" (2007) 18 Journal of Banking and Financial Law and Practice (Australia) $72-77$.

${ }^{186}$ In general, for the irregular deposit, see Robert W Lee, The Elements of Roman Law with a Translation of the Institutes of Justinian, 4th ed (London: Sweet \& Maxwell, 1956) at 295 and R. Zimmermann, The Law of Obligations-Roman Foundations of the Civilian Tradition (Cape Town: Juta, 1990) at 215-19.

${ }^{187}$ Goodfriend, supra note 32 at 261 . Bank regulation could be added to the listed items.

${ }^{188}$ Samid, supra note 129 at 105-106.

189 Such are:

i) closed/“in-game only’ schemes, in which a link to the real economy or fiat currency hardly exists; ii) schemes with unidirectional flow, under which the currency may originally be purchased with a fiat currency but may not be converted back to it, such as Facebook Credits, and even; iii) schemes with a bidirectional flow, envisaging conversion in both directions, albeit usually not used in entirely open loops throughout the entire economy, such as air miles in Frequent Flyer Programs
} 
coins that could be liquefied and redeemed, so as to be available for use in real trading, as well as for purchase of goods and services. Payment by such digital coins has the potential of bypassing both the bank account and the centralized multilateral interbank settlement.

A digital currency may be issued either privately or by a central bank. ${ }^{190}$ When it is issued privately it may have its own unit of account. ${ }^{191}$ Either way, a scheme in which coins are issued and redeemed under a centralized protocol is said to be centralized. ${ }^{192}$ A digital currency that is issued, transferred, and redeemed over a distributed ledger is decentralized. Finally, a digital currency transferable over a distributed ledger and yet issued by a centralized operator is hybrid. ${ }^{193}$

The distributed ledger underlying decentralization is an asset database that can be shared across a network of multiple sites, geographies or institutions. ${ }^{194}$ Blockchain is an underlying technology, requiring the Internet to support and maintain its peer-to-peer network, that enables digital implementation of a distributed ledger. Being a computerized ledger on a distributed network, it generates a single version of the record on each computer and in essence is: ${ }^{195}$

a type of a database that takes a number of records and puts them in a block ... Each block is then 'chained' to the next block, using a cryptographic signature. This allows block chains to be used like a ledger, which can be shared and corroborated by anyone with the appropriate permissions.

Accuracy of the ledger is corroborated under a method determined under rules adhered by

See European Central Bank/Eurosystem, Virtual Currency Schemes (October 2012) at 12-15, online:

<https://www.ecb.europa.eu/pub/pdf/other/virtualcurrencyschemes201210en.pdf>, accessed 12 March 2018. For an explanation as to why such a currency will not "migrate" to the real economy, see, e.g. Gans and Halaburda, supra note 158.

${ }^{190}$ For the latter, see e.g. CPMI, Central bank digital currencies (Basle: BIS, March 2018), online: https://www.bis.org/cpmi/publ/d174.pdf (visited October 07, 2018). See also Norges Bank Papers NO 1. 2018 : Central bank digital currency, on line: https://static.norgesbank.no/contentassets/166efadb3d73419c8c50f9471be26402/nbpapers-1-2018centralbankdigitalcurrencies.pdf?v=05/18/2018121950\&ft=.pdf , accessed October 7, 2018

${ }^{191}$ Denomination in its own unit of account appears to be an element in the definition of 'virtual currency' (that is, privately issued digital currency) in IMF Staff Discussion, Virtual Currencies and Beyond: Initial Considerations (January 2016), at 7 available at: https://www.imf.org/external/pubs/ft/sdn/2016/sdn1603.pdf [Accessed 21 September 2016].

${ }^{192}$ I am using this term here in a different sense than Liam Pak Nian and David Lee Kuo Chuen in in David Lee Kuo Chuen, ed, Handbook of Digital Currency: Bitcoin, Innovation, Financial Instruments and Big Data, (Amsterdam etc. Elsvier, 2015), at 7, who use it to denote "closed system[s\} with transactions within specific entities" in such items as loyalty points or airmiles.

${ }^{193}$ For this tripartite classification, see IMF Staff Discussion, Virtual Currencies supra note 191 (where a third criterion is added viz., "mechanisms to implement and enforce internal rules on the use and circulation of the currency").

${ }^{194}$ UK Government Office for Science, "Distributed Ledger Technology: beyond block chain" (2016) at 17-18, online: <https://www.gov.uk/government/uploads/system/uploads/attachment_data/file/492972/gs-16-1-distributedledger-technology.pdf $>$, accessed 28 December 2017.

195 UK Government Office for Science, Ibid at 17. See also e.g. CPMI, Distributed ledger technology in payment, clearing and settlement system - An analytical framework (Basel: BIS, February 2017), online:

<http://www.bis.org/cpmi/publ/d157.pdf >, accessed 28 December 2017; and David Mills, Kathy Wang et al., "Distributed ledger technology in payments, clearing and settlement" (2016) Federal Reserve Board Division of Research \& Statistics and Monetary Affairs Finance and Economics Discussion Series 2016-095, online: <https://www.federalreserve.gov/econresdata/feds/2016/files/2016095pap.pdf>, accessed 28 December 2017. 
participants. Record security and visibility to authorized users is ensured by cryptography.

A "cryptocurrency" denotes a digital currency in which encryption techniques are used to regulate the generation of units of currency and verify the execution of payment transactions ${ }^{196}$ on a decentralized network. Cryptography is thus used in cryptocurrencies to express and protect the value of the coins (the sequence of the bits), to prevent counterfeiting and fraudulent transactions, as well as to perform the validation and execution of transactions records via a distributed ledger, such as the blockchain. Each block contains a cryptographic hash ${ }^{197}$ or algorithm that links it to the previous block along with a timestamp for the transactions from that block. The network allows online payments to be sent directly from one party to another without going through a bank or any other centralized counterparty. ${ }^{198}$

The pioneering digital cash scheme, and the most prominent one so far, is Bitcoin. ${ }^{199}$ Being "the first and still the most popular cryptocurrency," it began life as a techno-anarchist project to create an online version of cash, a way for people to transact without the possibility of interference from malicious governments or banks" ${ }^{200}$ It is a virtual, ${ }^{201}$ self-anchored ${ }^{202}$ cryptocurrency and a peer-to-peer decentralized system. ${ }^{203}$ In his seminal paper, ${ }^{204}$ its

196 This definition slightly modifies the one from https://medium.com/@Wolfofcrypto/basic-cryptocurrency-starterguide-8f2071 ea85de; particularly, I replace 'transfer of funds' by the 'execution of payment transactions' to point at payment by the transmission of 'coins' rather than 'generic value' in the forms of funds.

197 "Hashing" was defined to be "a cryptographic technique to generate a unique code to represent [a] document which keeps the contents of that document confidential [so as] to verify that [it] exists and has not been tampered with." See: "Discussion Paper on distributed ledger technology" Financial Conduct Authority Discussion Paper DP 17/3 at 18, online: 〈https://www.fca.org.uk/publication/discussion/dp17-03.pdf>, accessed 28 December 2017. ${ }^{198}$ See e.g. Nian \& Chuen, supra note 192 at 5 and 8.

${ }^{199}$ In the broader context of subsequent "plenty of alternatives" see e.g. Andreas Hanl, "Some Insights into the Development of Cryptocurrencies" (2018) MAGKS Joint Discussion Paper Series in Economics No 04-2018, online: 〈https://www.uni-marburg.de/fb02/makro/forschung/magkspapers/paper_2018/04-2018_hanl.pdf〉, accessed 12 March 2018.

200 The Economist September 1st, 2018 p. 14

${ }^{201}$ See e.g. definition in s.102(23 of the Uniform Regulation of Virtual Currency Businesses Act, online: <http://www.uniformlaws.org/Act.aspx?title=Regulation\%20of\%20Virtual-Currency\%20Businesses\%20Act> accessed 28 December 2017, under which "[v]irtual currency" is "a digital representation of value that is used as a medium of exchange, a unit of account, or a store of value; and is not legal tender..." "Legal tender" is defined in s.102(8) as "the medium of exchange or unit of value, including the coin or paper money of the United States, issued by the United States or by another government."

${ }^{202}$ Namely, its value is not pegged to that of a financial asset or commodity.

${ }^{203}$ See e.g. Stuart Hoegner, "What is Bitcoin?" in Stuart Hoegner, ed, The Law of Bitcoin (Bloomington IN: iUniverse, 2015) at 1; Neil Guthrie, "The End of Cash? Bitcoin, the Regulators and the Courts" (2014) 29 BFLR 355. For its mechanics, see Jonathan Levin, "Bitcoin: New Plumbing for Financial Services", coindesk (29 November 2014), online: 〈http://www.coindesk.com/bitcoin-new-plumbing-financial-services/>, accessed 28 December 2017. See also Nicholas Wenker, "Online Currencies, Real-World Chaos: The Struggle to Regulate the Rise of Bitcoin" (2015) 19 Tex Rev L \& Pol 145; and Jacob Hamburger, "Bitcoins vs. State Money Transmission Laws: Protecting Consumers or Hindering Innovation?” (2015) 11 J L Econ \& Pol'y 229. See also: $<$ https://en.wikipedia.org/wiki/Bitcoin>, accessed 28 December 2017; <http://www.coindesk.com/information/whatis-bitcoin/ $>$, accessed 28 December 2017; http://www.wired.com/2011/11/mf_bitcoin/, accessed 28 December 2017; and "The Great Chain of Being Sure About Things", The Economist (31 October 2015). See also European Central Bank/Eurosystem, supra note 189 at 21-24 and <https://en.bitcoin.it/wiki/How_bitcoin_works>, accessed 28 December 2017.

${ }^{204}$ Satoshi Nakamoto, "Bitcoin: A Peer-to-Peer Electronic Cash System" (2008) at 2, online: <https://bitcoin.org/bitcoin.pdf>, accessed 28 December 2017. 
mythological founder Satoshi Nakamoto defined Bitcoin as an "electronic coin" consisting of a "chain of digital signatures" transferable from the payer to the payee "by digitally signing a hash of the previous transaction and the public key of the next owner and adding them to the end of the coin.”. Premised on distributed ledger technology (DLT), Bitcoin was born out of an ambition to create government-independent, censorship-resistant money.

Bitcoin network consists of independent nodes, each operated by a 'miner'. Miners then bundle each proposed payment with others and create a new block for the blockchain. The new block is hashed and, together with other data, is rehashed. The data is repeatedly fed through a cryptographic 'hash' function. The hash is put into the header of the proposed block and becomes the basis for a mathematical puzzle. The 'miners' compete to reach a solution for it, and the first to come up with the right solution, as accepted by the majority of miners who submitted 'proof of work', ${ }^{205}$ is rewarded with newly 'minted' bitcoins. The mathematical puzzle is hard to solve, but once found, it is easy for the network to confirm that the answer is correct. Nodes accept the block, whose header contains the hash of the previous block's header, by adding it to the chain that stretches back to the first Bitcoin block (the genesis block), containing the first transaction in the Bitcoin network. This construction is designed to make the Bitcoin blockchain tamperproof: if one tries to fake a transaction by changing a block that had already been stored in the blockchain that block's hash would be different and ought to be apparent to all as having been tampered with. The 'coin' thus carries with it its entire history so that each payment becomes part of its code.

Payments are made from one Bitcoin wallet to another. Each such wallet is a computer file or a software program which has an email address. The wallet stores both the private key (in effect the passcode) and the bitcoin ${ }^{206}$ balance controlled by it. What is transferred is 'monetary fluid' representing the bitcoin sum accessed from the payer's wallet and originating from all Bitcoin 'coins' accessed from that wallet. ${ }^{207}$ Stated otherwise, a payer is unable to designate and set aside for payment any particular bitcoin. In effect, payment can be made in any sum available from the wallet, and regardless, at the end of the process, new bitcoins become associated with the payee's wallet, while those still associated with the payer's wallet may have changed their value and hence their identity. Transaction output is thus said to differ from transaction input, if only due to the diversified chain of provenance of input (from the payer's wallet). It would have been more accurate to speak of a Bitcoin payment resulting in a 'coin' being transformed rather than transferred, except that each resulting 'coin' carries with it identities of its predecessors as well as the impact of its subsequent partial use. Transaction information is stored on the blockchain; strictly speaking, the 'coins' themselves are not discrete things and are thus not stored anywhere. As a string of bits they however exist in the wallet so that to access them one needs both the password and control over the physical device or cloud having the wallet. If the

\footnotetext{
205 'Proof of Work' is defined to require "that the decentralized participants that validate blocks show that they have invested significant computing power in doing so." See Fintechblue, "What is Proof of Work?" fintechblue, online: <http://www.fintechblue.com/2016/06/what-is-proof-of-work/>, 28 December 2017. According to Satoshi Nakamoto, ibid., "[p]roof-of-work is essentially one-CPU-one-vote," rather than "one-IP address-one-vote". ${ }^{206}$ Conventionally, "Bitcoin" (capitalized) refers to the technology and network whereas "bitcoins" (lowercase) refers to the currency, units and 'coins'.

${ }^{207}$ A participant may have indefinite numbers of such wallets. In any event, note that what is described in the text is the direct holding of bitcoins. Alternatively, in an indirect holding system, a participant keeps bitcoins with an intermediary. See Ryan J Straus and Matthew J Cleary, “The United States” in Hoegner, ed, supra note 203.
} 
device is lost, the use of the bitcoins remains available to the owner only where the wallet has been backed up (and the one in the device possession as well as with knowledge of the passcode has not spent them). ${ }^{208}$

It is argued that developers of cryptocurrencies "simply migrated the cryptographic tools used to safeguard communication and applied them to safeguard digital currency". ${ }^{209}$ Hence the vulnerability to erosive cryptographic intractability from which Bitcoin suffers, in addition to its vulnerability to potential leadership corruption. ${ }^{210}$ Also, its operation, whether in facilitating payments, preventing double spending, or issuing new bitcoins, requires substantial computational energy and is thus said to be wasteful. ${ }^{211}$ Bitcoin also suffers from poor scalability, as it can handle at most 7 transactions per second, ${ }^{212}$ compared to Visa and Mastercard that clear in a second 2,000 transactions, ${ }^{213}$ or even a peak-volume of 10,000 transactions per second. ${ }^{214}$

Certainly, however, Bitcoin is driven not only by technological innovation but also by strong sentiments ${ }^{215}$ against currency systems based on bank credit ${ }^{216}$ and backed by government. ${ }^{217}$ Its promoters cite its non-inflationary basis, ${ }^{218}$ partly attributed to the limitation on the number of bitcoins to be generated by its protocol. Indeed, in general, Bitcoin's value is

\footnotetext{
${ }^{208}$ For Bitcoin mechanics, see Levin, supra note 203. For more technical information see e.g. <https://bitcoin.stackexchange.com/questions/39101/what-happens-to-bitcoin-wallet-bitcoins-if-pc-is-stolen>; <https://bitcoin.stackexchange.com/questions/1600/where-are-the-users-bitcoins-actually-stored>; and $<$ https://bitcoin.stackexchange.com/questions/1600/where-are-the-users-bitcoins-actually-stored>, all accessed 9 January 2018.

${ }^{209}$ Samid, supra note 129 at 26. See also Samid, ibid at 101 for an argument against extrapolating cryptotools for transient communication to shielding digital currency.

${ }^{210}$ For details on the main bitcoin principles, see Samid, ibid at 108-116.

${ }^{211}$ See details at e.g. Christopher Malmo, "Bitcoin is Unsustainable", Vice: Motherboard (29 June 2015), online: <http://motherboard.vice.com/read/bitcoin-is-unsustainable>, accessed 28 December 2017; See also e.g. John Quiggin, "Bitcoins are a waste of energy-literally", ABC News (5 October 2015), online: <http://www.abc.net.au/news/2015-10-06/quiggin-bitcoins-are-a-waste-of-energy/6827940>, accessed 28 December 2017.

212 See e.g.

<https://en.bitcoin.it/wiki/Scalability_FAQ\#What_is_this_Transactions_Per_Second_.28TPS.29_limit.3F>, accessed 28 December 2017.

213 Saifedean Ammous, "Blockchain Technology: What is it good for?" (8 August 2016) at 2, online: <https://poseidon01.ssrn.com/delivery.php?ID=6970011271260741151271140771230800741030240360440860031 000751011251240800231240890291100320530221090490031200080680960980701151160830940220861200681 031221250251130980050650670200931231181110290040710920170230921210000250640041121230790761140 $65120009100 \& \mathrm{EXT}=\mathrm{pdf}>$, accessed 28 December 2017.

214 Timothy B Lee, "Bitcoin needs to scale by a factor of 1000 to compete with visa. Here's how to do it.", The Washington Post (17 November 2005), online: <https://www.washingtonpost.com/news/theswitch/wp/2013/11/12/bitcoin-needs-to-scale-by-a-factor-of-1000-to-compete-with-visa-heres-how-to-doit/?utm_term=.f6e09d78860d $>$, accessed 28 December 2017.

${ }^{215}$ For an overview, citing the sources as immediately below, see European Central Bank/Eurosystem, supra note 189 at $22-23$.

${ }^{216}$ Murray N Rothbard, Economic Depressions: Their Cause and Cure (Alabama: Ludwig von Mises Institute, 2009).

${ }^{217}$ Friedrich A Hayek, Denationalisation of Money, 3rd ed (London: The Institute for Economic Affairs, 1976).

${ }^{218}$ European Central Bank/Eurosystem, supra note 215.
} 
premised on its scarcity; ${ }^{219}$ its specific value as a monetary asset, in fact 'hard money', is the result of its high ratio of the stock to the flow. ${ }^{220}$ At the same time, in the long run, the finite number of bitcoins in existence may prove to adversely affect both prices and liquidity. ${ }^{221}$ Furthermore, the current 21 million cap is not engraved in stone and is thus subject to change. ${ }^{222}$ Regardless, as a self-anchored digital currency, Bitcoin is a mathematical creature; being unsupported by the economic might of an issuer, ${ }^{223}$ its principal weakness lies in the inherent instability of its value. ${ }^{224}$ In the absence of any "objective rational[e] for any exchange value" Bitcoin is thus likened to "a game that triggered universal interest ... [but whose] infirmity is as intrinsic as Monopoly money." Last but not least, a competitor's self-anchored math-based currency may emerge and thereby lower the Bitcoin value. This casts a shadow on the acceptability of Bitcoin as a real substitute to fiat currency. ${ }^{225}$

It has specifically been suggested that to meet its unstable value, Bitcoin should be pegged in one way or another to the value of a specific fiat currency or commodity. ${ }^{226}$ Albeit this can be done only at a heavy ideological cost to its promoters, who highlight Bitcoin's independence from any outside control on both the quantity and the value.

Other than scalability and an unstable value, the principal hurdle for a universal acceptance of cryptocurrencies in general and Bitcoin in particular as the money of the future is that decentralization and the resulting absence of a trusted central counterparty may be more of a curse than a blessing. ${ }^{227}$ In other words, efficiency gains in cutting out intermediaries come at costs which outweigh benefits. ${ }^{228}$ According to Saifeadean Ammous, inefficiency is inherent in the blockchain technology in general and Bitcoin in particular: ${ }^{229}$

${ }^{219}$ As pointed out by Saifedean Ammous, The Bitcoin Standard: The Decentralized Alternative to Central Banking (Hoboken NJ: Wiley, 2018) at 177, speaking of Bitcoin designer Nakamoto as the inventor of 'digital scarcity'. For scarcity as the source for the value of a monetary asset see Karl Polyani, "The Semantic of Money Use" in G Dalton (ed.), Primitive, Archaic and Modern Economies: Essays of Karl Polyani, (Darden City, NY: Doubleday, 1968) at $175,197$.

${ }^{220}$ Ammous, The Bitcoin Standard ibid. at 5-6, 23, 155, and 199-200.

${ }^{221}$ Samid, supra note 129 at 113.

${ }^{222}$ Hoegner, ed, supra note 203 at 1, 9 n. 57.

${ }^{223}$ Samid, supra note 129 at 14-16.

${ }^{224}$ For a discussion on the nature of Bitcoin value, see e.g. William J. Luther, "Is Bitcoin Intrinsically Worthless?" (July 2017), online: https://papers.ssrn.com/sol3/papers.cfm?abstract_id=3000068, accessed 28 December 2017.

${ }^{225}$ Samid, supra note 188 at 14-15 (for an illustration of instability), and 109-110 (for connection between selfanchoring and instability). The quotation is from p. 15.

${ }^{226}$ Samid, ibid at 114-121. Cf. e.g. NationCoin, being a proposed Regulated and Sovereign Backed Cryptocurrency (RSBC). Its scheme envisages cryptocoins, which as in Bitcoin, will be created by and transacted over a blockchain. However, upon their creation, cryptocoins will be stored, and released to the public by a Digital Asset Reserve, as RSBC, at the fixed value of the national unit of account. Transactions are to be verified by 'miners' who will be paid freshly minted cryptocoins. See Kartik Hegadekatti and Yatish S G, "Generation, Security and Distribution of MationCoins by a Sovereign Authority" (7 Jan 2017), online:

<https://papers.ssrn.com/sol3/papers.cfm?abstract_id=2888347>, accessed 28 December 2017.

${ }^{227}$ For an interesting historical study on the lessons from the misfortune of such absence see eg. Isabel Schnabel and Hyun Song Shin, Money and trust: lessons from the 1620 for money in the digital age (Basel: BIS, February 2018) online: <https://www.bis.org/publ/work698.pdf>, accessed 12 March 2018.

${ }^{228}$ A point highlighted Mark Carney, Speech: The Future of Money (Bank of England, March 2, 2018) at 6-9, online: https://www.bankofengland.co.uk/-/media/boe/files/speech/2018/the-future-of-money-speech-by-markcarney.pdf?la=en\&hash=A51E1C8E90BDD3D071A8D6B4F8C1566E7AC91418 .

${ }^{229}$ Ammous, supra note 213 at 2. 
Bitcoin has a blockchain not because it allows for faster cheaper transactions, but because it removes the need to trust in third party intermediation transactions are cleared because nodes compete to verify them, yet no node needs to be trusted. It is unworkable for third party intermediaries to imagine they could improve their performance by employing a technology that sacrifices efficiency and speed precisely to remove third party intermediaries. For any currency controlled by a central party, it will always be more efficient to record transactions centrally. Whether removing third party intermediation is a strong enough advantage to justify the increased inefficiency of distributed ledgers is a question that can only be answered over the coming years in the test of market acceptance of digital currencies. What can be clearly seen is that blockchain payment applications will have to be with the blockchain's own decentralized currency, and not with centrally-controlled currencies.

Elsewhere Ammous explains that it is the high processing power threshold which prevents both hacking and the establishment of a central control. Both achievements secure neutrality and full benefit of decentral structure for Bitcoin, and yet at the cost of a fixed supply of growth that cannot be made to adjust to satisfy a purely market-determined demand and hence results in price instability. At the same time, he observes, attempts in other currencies to bypass the expensive, inefficient and wasteful Proof of Work (PoW), by other settlement mechanisms such as Proof of Stake, ${ }^{230}$ consensus, or a trusted notary, compromise the neutrality of the system, enhance the control of the issuer, and/or require a third party verificator, all at the expense of the DLT premises. Hence, he concludes, Bitcoin could be no more than a store of value ${ }^{231}$ while other cryptocurrencies cannot fulfill any monetary feature. ${ }^{232}$

Ammous does not see the deflationary nature of Bitcoin as an impediment to its unit of account function. At the same time, having highlighted Bitcoin's inadequacy to serve as a medium of exchange for everyday transactions, he argues that Bitcoin may be "the best store of value humanity ever invented" so as to be capable of functioning as "a reserve currency" to be

\footnotetext{
${ }^{230}$ For the difference between proof of work and proof of stake see e.g.: https://www.google.ca/search?rls=com.microsoft:en-

CA:IEAddress\&dcr=0\&q=what+is+the+difference+between+proof+of+work+and+proof+of+stake?\&spell=1\&sa= X\&ved=0ahUKEwj38Knl1azYAhUm94MKHekWAF8QvwUIJigA\&biw=1094\&bih=625>, accessed 28 December 2017.

${ }^{231}$ Not everybody is in agreement. For considering Bitcoin to be an "imperfect store of value" due to its volatility see Aaron Kumar and Christie Smith, "Crypto-currencies - An introduction to not-so-funny moneys" (November 2017) Reserve Bank of New Zealand Analytical Note Series, AN2017/07 at 2, online: <https://www.rbnz.govt.nz//media/ReserveBank/Files/Publications/Analytical\%20notes/2017/an2017-07.pdf>, accessed 9 January 2018.

${ }^{232}$ Saifedean Ammous, "Can cryptocurrencies fulfill the functions of money?" (August 2016), online: <https://poseidon01.ssrn.com/delivery.php?ID=89803106806902001308410009400111511302400804906803>, accessed 05 October 2018 .
} 
held by banks in cold storage. ${ }^{233}$ Against the Bitcoin reserve banks will perform payment transactions by debiting payers' accounts and crediting those of payees. With Bitcoin reserve banks will settle. However, other than eliminating the central bank, this model will mimic the role of banks in relation to payments in fiat currencies so that everyday Bitcoin transactions will be carried out 'off-chain' in effect through banks or similar deposit taking institutions. ${ }^{234}$

Drawbacks in the utilization of decentralized digital currency schemes have led the way to the consideration of centralized digital currencies issued by trusted issuers such as either central banks or private issuers. In the ongoing fight against counterfeiters and fraudulent copiers centralized schemes are better positioned to apply superior defence measures in protecting the integrity of the data base, as well as enhanced security procedures in both coin and identity verification upon redemption and in trade. ${ }^{235}$ This is without mentioning the higher scalability of a centrally issued digital coin scheme. Two such technologies are set out below.

Wing Cash is a centralized system, allowing the issuer to determine the reserve requirement, under which a claim-check to fiat currency may be issued. ${ }^{236}$ It has a multi-issuer platform using a centralized model, allowing for the ledger to replicate in multiple locations. Each claim-check is in the form of a unique web page with an immutably assigned web address (URL), typically cryptographically signed by the issuer. It is described as a digital bearer instrument with a fixed value which simulates a physical banknote. Each digital bearer instrument has a single 'possession' attribute so that only the current holder can reassign 'possession' to another entity. The ledger immediately records the update to the 'possession' attribute to avoid the double-spending problem. As in the case of physical cash, the change of possession from one holder to another constitutes a payment. Therefore, the ledger keeps a record of the change of 'possession' of each bearer instrument. Digital notes may be redeemed to

\footnotetext{
${ }^{233}$ Ammous, The Bitcoin Standard supra n.219 at 198 and 207, respectively. For predicting that Bitcoin will achieve gold parity so as to cause in gold value to decrease see e.g. Katrik Hegadekatti, "Blockchain Technology An instrument of Economic Evolution?” (2017) MPRA Paper No 82852, online: online: <https://mpra.ub.unimuenchen.de/82852/1/MPRA_paper_82852.pdf>, accessed 12 March 2018. Not everybody is in agreement: Tony Klein, Pham Thu Hien and Thomas Walther, "Bitcoin Is Not the New Gold: A Comparison of Volatility, Correlation, and Portfolio Performance" (2018), 59 International Review of Financial Analysis, online : https://poseidon01.ssrn.com/delivery.php?ID=92200506511000207301807107012501210003005005007806802009 208510407206700610100808310302900103312702700102909210308502906402009401603907400000209711501 501206502502010705809207700203009802712009110302101710200110007011306912206611311706906509903 $1115022117 \& \mathrm{EXT}=\mathrm{pdf}$, accessed October 07, 2018.

${ }^{234}$ For a more moderate hypothetical variation, under which currency issued under the Bitcoin standard will consist of Bitcoin, as well as fiduciary currencies issued by central banks and commercial bank money, both backed by Bitcoin, and in which central banks will continue to be lenders of last resort, see Warren E Weber, "A Bitcoin Standard: Lessons from the Gold Standard" (2016) Bank of Canada, Staff Working Paper 2016-14, online: <https://www.bankofcanada.ca/wp-content/uploads/2016/03/swp2016-14.pdf>, accessed 9 January 2018.

${ }^{235}$ See e.g. Samid supra n. 129 at 92-94 and $c f$. ibid. at 125-27 as well as at 25, 98-100 albeit focusing on the advantage of paying with digital coins over that of paying in scriptural money which may expose account data to hackers.

${ }^{236}$ For some information visit <www.wingcash.com>, accessed 28 December 2017 as well as <www.wingcash.org>, accessed 28 December 2017.
} 
fiat currency in the form of either physical cash or bank money. Among 17 faster payments solutions, ${ }^{237}$ WingCash's solution for digital Fedbotes ${ }^{238}$ came tied in the first place. ${ }^{239}$

The second technology is that of BitMint facilitating a centralized scheme for a nonspeculative and stable currency, consisting of randomized coins, each expressing a claim-check to a defined quantity of a specific commodity, including a fiat currency. ${ }^{240}$ It may also be cascaded so as to be denominated in a unit of account anchored on the value of two or more fiat currencies, commodities, or indices. ${ }^{241}$ BitMint money is generated through an economical quantum mechanical process ${ }^{242}$ which is energy-efficient and reduces waste. BitMint keeps $100 \%$ reserve so that the purchasing commodity or fiat currency is always available for redemption on demand. BitMint is said to be identified as "the only candidate qualifying as a universal digital representation of worldwide currencies." 243

BitMint currency is protected by quantum physics, not dependent on erosive encryption, and claimed to be indefeasible by cyber threats. ${ }^{244}$ It has a Validation Hierarchy under which coins are validated through subordinate nodes and may be tethered ${ }^{245}$ so as to be "[m]oney with built-in limitation on its use" ${ }^{, 246}$ such as where a coin is cryptographically linked to the rightful owner. ${ }^{247}$ Tethering may also facilitate crypto-fusing contractual terms between payer to payee into the money, so as to disallow any use that is in breach of the contract. BitMint money can be split off or amalgamated at any desired resolution ${ }^{248}$ and can be paid continuously on a pay-asyou-go basis, e.g. as you pump gas into a car gas tank, rather than separately, e.g. upon the

237 "Strategies for Improving U.S. Payment System” (26 January 2015) Federal Reserve System, online: <https://fedpaymentsimprovement.org/wp-content/uploads/strategies-improving-us-payment-system.pdf>, accessed 28 December 2017.

${ }^{238}$ WingCash (Proposer), "Faster Payments QIAT" (21 February 2017) at 11 and 14, online: <https://drive.google.com/file/d/0B_CNPQWTRQwuZWhqbDUzNVJsNGc/view>, accessed 28 December 2017. For extensive information, see documents ibid. at 13: <http://fasterpaymentsnetwork.com/>, accessed 28 December 2017; <https://drive.google.com/file/d/0B_CNPQWTRQwuc1hhWlAzOEljNGs/view>, accessed 28 December 2017; and <https://drive.google.com/file/d/0B_CNPQWTRQwuZWhqbDUzNVJsNGc/view>, accessed 28 December 2017.

${ }^{239}$ See "The U.S. Path to Faster Payments FINAL REPORT PART TWO: A CALL FOR ACTION" (July 2017) Faster Payments Task Force at 13, online: <https://fasterpaymentstaskforce.org/wp-content/uploads/fasterpayments-task-force-final-report-part-two.pdf>, accessed 28 December 2017.

${ }^{240}$ For detailed information on BitMint (not to be confused with BitMinter), see e.g.: < http://www.bitmint.com/>, accessed 12 March 2017; <http://finder.startupnationcentral.org/company_page/bitmint/>, accessed 12 March 2017 , and sites and videos accessible through it; and <https://medium.com/@ bitmintnews>, accessed 12 March 2017, and associated articles.

${ }^{241}$ Samid, supra note 129 at 22.

242 On this process, see e.g. <https://en.wikipedia.org/wiki/Introduction_to_quantum_mechanics>, accessed 28 December 2017.

${ }^{243}$ See this quote from Helmut Scherzer, Senior Principal Technology Manager for Giesecke \& Devrient at the Chip-to-Cloud Security Forum, held September 25-17, 2013, Nice, French Riviera. It is online at slide no. 16 in <http://pennwell.sds06.websds.net/2015/amsterdam/slideshows/T1S7O3-slides.pdf>, accessed 28 December 2017. ${ }^{244}$ For details, see Gideon Samid, "Bitcoin.BitMint: Reconciling Bitcoin with Central Banks", BitMint, LLC, online: <https://eprint.iacr.org/2014/244.pdf>, accessed 28 December 2017. See also e.g.

<http://www.bitmint.com/bitcoin.htm>, accessed 28 December 2017.

${ }^{245}$ Samid, supra note 129 at 108.

${ }^{246}$ Samid, ibid. at 140 (Glossary).

${ }^{247}$ Samid, ibid at 50 and 100.

${ }^{248}$ For details on randomized or entropic coins, see Samid, ibid. at 106-108. 
completion of the service.

In the final analysis a centralized digital currency system is modeled on a "note-based" e-money scheme discussed in Part IV, except that due to technological advancements the chance is that it entails higher if not unlimited circulation of coins among a larger if not unlimited number of participants. Facilitating payment from one device to another without communication to a bank may revolutionize both payments and money holding patterns. However, inasmuch as digital coins are to be bought with bank money and ultimately may be redeemed in bank money, a centralized digital currency scheme, while being bound to change means and methods of payment, will arguably not change fundamentals as to the quantity of money and the role of banks in its creation and transmission. ${ }^{249}$

Notwithstanding drawbacks set out earlier in this section, a few central bank decentralized or hybrid digital currency schemes, namely using the blockchain at least for settlement, have been floating. ${ }^{250}$ In the US, proposals have been made for Fedcoin, being a central bank-issued centrally created cryptocurrency, to be available to the public at large. ${ }^{251}$ Digital coins are to be centrally issued on a blockchain-style decentralized ledger, but nevertheless with the central bank being in full control of quantity, timing, and fixed value ibn denominations of the national fiat currency unit of account. Effectively, transactions will be validated by an independent notary nominated by the central bank. A similar proposal was made in the UK for RSCoin. ${ }^{252}$ Another proposal is for a NationCoin, being a Regulated and Sovereign Backed Cryptocurrency (RSBC). The scheme envisages cryptocoins, which as in Bitcoin, will be created by and transacted over a blockchain. Upon their creation, cryptocoins will be stored, and released to the public by a Digital Asset Reserve, as RSBC, at the fixed value of the national unit of account. Transactions are to be verified by 'miners' who will be paid freshly minted cryptocoins. $^{253}$

\footnotetext{
${ }^{249}$ For a similar conclusion regarding (broadly and loosely defined) central bank digital currency, see Jack Meaning, Ben Dyson, James, Barker and Emily Claydon, Broadening narrow money: monetary policy with a central bank digital currency, Staff Working Paper no. 724, Bank of England, May 2018, online: file:///C:/Users/bgeva/AppData/Local/Temp/Broadening.pdf accessed October 7, 2018.
}

${ }^{250}$ See: Morten Bech and Rodney Garratt, "Central bank cryptocurrencies” (2017) BIS Quarterly Review, at 55, online: 〈https://www.bis.org/publ/qtrpdf/r_qt1709f.pdf>, accessed 12 March 2018. See also: Katrik Hegadekatti, "Towards Regional Monetary Unions through Blockchain Networks" (2017) MPRA paper No 82838, online: <https://mpra.ub.uni-muenchen.de/82838/>, accessed 12 March 2018; and Heike Mai, "Why would we use crypto euros? Central bank-issued digital cash - a user perspective" (2018) EU Monitor Global financial markets, online: <https://www.dbresearch.com/PROD/RPS_EN-PROD/PROD0000000000462095.PDF>, accessed 12 March 2018. For centralized, decentralized and hybrid digital currency schemes see text at notes 190-93 supra.

${ }^{251}$ See e.g. Wendy McElroy, "Fedcoin: The U.S. Will Issue E-Currency That You Will Use”, Bitcoin.com (12 January 2005), online: <https://news.bitcoin.com/fedcoin-u-s-issue-e-currency/>, accessed 28 December 2017.

${ }^{252}$ See George Danezis and Sarah Meiklejohn, Centrally Banked Cryptocurrencies (London: University College London, 2015), online: 〈https://eprint.iacr.org/2015/502.pdf〉, accessed 28 December 2017. In part this article is too technical to the uninitiated in computer science and related subjects (including myself). "RSCoin is the core of a system of scalable and auditable transactions, not a full product" which thus could be used as a basis for either a retail or wholesale product. Email message to the author from George Danezis dated 4 December 2017. 
As a proof of concept (PoC) both Bank of Canada under the Jasper Project ${ }^{254}$ and Monetary Authority of Singapore under the Ubin Project ${ }^{255}$ experiment a DLT-based wholesale payment system premised on the use of a blockchain for interbank settlement in central bank money. Thereunder, the central bank issues to each participating bank digital depository receipts against the security of funds withdrawn from the reserve account of that bank. For each payment order processed, interbank settlement continuously takes place by transacting with these digital receipts over the blockchain. Both entered a collaboration to test and develop a cross-border solution using crypto tokens issued by the two central banks. ${ }^{256}$

In Jasper, Digital Depository Receipts (DDRs) issued by the Bank of Canada are secured by an omnibus account in which each participating bank deposits central bank money withdrawn from its settlement account. In Ubin, Depository Receipts (DRs) are issued by the Monetary Authority to each participating bank against central bank money deposited by the latter in an individual cash custody account held with the former. In Ubin participating banks may hold deposit receipt balances on the blockchain overnight and have greater flexibility in pledging and redeeming DRs during operating hours. In Jasper DDRs are created and destroyed upon redemption on a daily basis.

Ubin uses a system built on the Ethereum platform. This was true for the first phase of Jasper (Jasper 1). This platform uses Proof of Work (PoW) consensus protocol, requiring expensive computations to validate transactions and update the ledger. For that reason the second

\footnotetext{
${ }^{253}$ Kartik Hegadekatti and Yatish S G, "Generation, Security and Distribution of MationCoins by a Sovereign Authority" (7 Jan 2017), online: <https://papers.ssrn.com/sol3/papers.cfm?abstract_id=2888347>, accessed 28 December 2017.
}

254 See: James Chapman, Rodney Garratt et al., "Project Jasper: Are Distributed Wholesale Payment Systems Feasible Yet?” (2017) Bank of Canada Financial System Review, online: <http://www.bankofcanada.ca/wpcontent/uploads/2017/05/fsr-june-2017-chapman.pdf>, accessed 28 December 2017. For the earlier stage of the project see Rod Garratt, “CAD-coin versus Fedcoin” (May 2017), online: <https://www.finextra.com/finextradownloads/newsdocs/cad-coin-versus.pdf>, accessed 28 December 2017. Also see:

Laura Shin, "Canada Has Been Experimenting With A Digital Fiat Currency Called CAD-COIN", Forbes (16 June 2016), online: <http://www.forbes.com/sites/laurashin/2016/06/16/canada-has-been-experimenting-with-a-digitalfiat-currency-called-cad-coin/\#536fabe91b0c>, accessed 28 December 2017; Pete Rizzo, "Bank of Canada Demos Blockchain-Based Digital Dollar", CoinDesk.com (16 June 2016), online: <http://www.coindesk.com/bank-canadademos-blockchain-based-digital-dollar/>, accessed 28 December 2017; and Claire Brownell, "No cryptocurrency anytime soon, Bank of Canada says: 'We're very far off'", Financial Post (17 June 2016), online $<$ http://business.financialpost.com/news/fp-street/no-cryptocurrency-anytime-soon-bank-of-canada-says-were-veryfar-off $>$, accessed 28 December 2017.

${ }^{255}$ See: Deloitte \& MAS (Monetary Authority of Singapore), "The future is here - Project Ubin: SGD on Distributed Ledger" (2017), online:

<http://www.mas.gov.sg/ /media/ProjectUbin/Project\%20Ubin\%20\%20SGD\%20on\%20Distributed\%20Ledger.pdf $>$, accessed 28 December 2017.

256 Speech by Ravi Menon, Managing Director, MAS, at Money20/20, today, 15 March 2018: http://www.mas.gov.sg/News-and-Publications/Speeches-and-Monetary-Policy-Statements/Speeches/2018/CryptoTokens-The-Good-The-Bad-and-The-Ugly.aspx?from=timeline\&isappinstalled=0 (accessed March 19 2018). 
phase of Jasper (Jasper II) switched to the Corda platform in which a notary function replaces that of the PoW: ${ }^{257}$ The notary role in Jasper II is assigned to the Bank of Canada. As such it has access to the entire ledger and is able to verify that the funds involved in a transaction are available.

Jasper II improved on both Jasper 1 and Ubin in facilitating a liquidity-saving mechanism (LSM) in the form of a payment queue with periodic multilateral payment netting for payments designated as 'non-urgent'.

Both Jasper and Ubin have been successful as a proof of concept for a DLT-based interbank settlement system that has the potential of replacing the traditional Real-time Gross Settlement (RTGS). However, in assessing Jasper, it was concluded that: ${ }^{258}$

- For critical financial market infrastructures, such as wholesale payment systems, current versions of DLT may not provide an overall net benefit relative to current centralized systems. Recent versions of DLT have, however, made advances compared with initial cryptocurrency applications of DLT.

- Benefits for the financial system of a DLT-based wholesale payment system could likely arise from its interaction with a larger DLT ecosystem of financial market infrastructures, potentially including cross-border transactions

Ultimately, blockchain technology may supplement and be integrated into existing financial infrastructure, and yet does not appear to replace it altogether.

\section{Conclusion}

In migrating "cryptographic tools used to safeguard communication and appl[ying] them to safeguard digital currency" 259 cryptocurrency developers effectively engineered payment disintermediation. They did so by means of tools that originally fashioned to enhance payment intermediation through safeguarding interbank as well as customer-to-bank and bank-tocustomer communication. Once issues of volatility, scalability and deflation are resolved, cryptocurrencies have indeed the potential to generate means of payment "offering much of the anonymity of cash while also allowing transactions at long distances" and yet "clear and settle quickly without an intermediary." 260 Ironically then, it is the evolution of a process in banking, enhancing payment intermediation, which could lead to the demise of banks as payment intermediaries. The result will not change even if centralized digital currencies are to supersede cryptocurrencies.

\footnotetext{
257 James Chapman, Rodney Garratt et al., supra note 254 at 5.

258 James Chapman, Rodney Garratt et al., ibid. at 1.

${ }^{259}$ Samid, supra note 129 at 26. See text @n. 209, supra.

${ }^{260}$ Donge He, "Monetary Policy in the Digital Age," IMF Finance \& Development 13 (June 2018).
} 
However, in my view, the chance is that the demise of both banks and payment intermediation will not happen or at least not anytime soon. Certainly, we shall see some measure of payment disintermediation in the form of improved cryptocurrencies as well as centralized digital currencies. At the same time, banks have been fighting back to improve their own legacy systems. Thereby they may successfully compete with digital currency payment services providers. For its part, a successful centralized digital currency system is likely to count on commercial banks buying and selling the currencies into and out of accounts maintained with them so as to become a universal "note-based" e-money scheme linked to banks and the legacy monetary system.

Regardless, it is hard to see banks as both depositaries and lenders of money disappear. Rather, they are likely to get themselves into the digital currency space and provide services as well as be in a position to cover risks that customers would prefer not to incur on their own. As well, there is a good chance that in competing with banks, IT firms issuers of digital currencies will become rather than supersede banks. And even if crypto assets may one day reduce demand for central bank money I doubt that the public will be ready to have control on the quantity of money surrendered to digital currency developers. Whether centralized digital currencies are to be traded with or issued by commercial banks, or whether central banks are to take over from the private sector the issue of digital currencies, whether under a centralized or decentralized scheme, changes to monetary policy will not be substantial even if the use of banks as payment intermediaries will be affected.

Possibly, both practicalities and anti-money laundering \& terrorist financing regulations may limit the size of payments to be made in digital currencies. Furthermore, the chance is that for a large payment, an RTGS system, with liquidity-saving mechanisms, settled between commercial banks on the books of a trusted central bank, will be preferred by participants over a large peer to peer digital cash payment between them. ${ }^{261}$ For now, the scope and magnitude of future developments can only be speculated.

\footnotetext{
${ }^{261}$ See e.g. Walter Engert and Ben S C Fung, "Central Bank Digital Currency: Motivations and Implications”, Bank of Canada, Staff Discussion Paper 2017-16 at 16-17, online: <https://www.bankofcanada.ca/wpcontent/uploads/2017/11/sdp2017-16.pdf>, accessed 9 January 2018.
} 